\title{
Domniemane i rzeczywiste kontakty prominentów nazistowskich z polskością przed 1933 rokiem
}

Niezwykle interesująca problematyka stosunku Hitlera i narodowych socjalistów do Polski i Polaków znalazła odbicie w rzetelnych pracach rodzimych badaczy (J.W. Borejsza, T. Szarota, E.C. Król, H. Orłowski) ${ }^{1}$. Chciałbym się skupić w niniejszym skromnym przyczynku na kontaktach, „spotkaniach” prominentów nazistowskich (choć jest to „nieostry” termin) ${ }^{2}$ z szeroko pojętą polskością (Polska, a właściwie ziemie polskie ${ }^{3}$, Polacy, kultura polska) przed „Machtübernahme", tj. przed 30 stycznia 1933 roku. Niniejsze rozważania absolutnie nie

1 J.W. Borejsza, Antyslawizm Adolfa Hitlera, Warszawa 1988; idem, Śmieszne sto milionów Stowian: wokót światopogladu Adolfa Hitlera, Warszawa 2006; T. Szarota, Niemcy i Polacy. Wzajemne postrzeganie i stereotypy, Warszawa 1996; E.C. Król, Polska i Polacy w propagandzie narodowego socjalizmu w Niemczech 1919-1945, Warszawa 2006; H. Orłowski, Polnische Wirtshchaft. Nowoczesny niemiecki dyskurs o Polsce, Olsztyn 1998.

${ }^{2}$ Za prominentów nazistowskich uznaję w tym przypadku nazistowskich posłów do Reichstagu (Mitglieder des Großdeutschen Reichstags) oraz „dębowców” SS i SA, tj. wszystkich wyższych oficerów od SS-Standartenführera i SA-Standartenführera wzwyż. Mam naturalnie świadomość „fasadowego" charakteru Reichstagu w Niemczech (podobnie zresztą było w Związku Sowieckim) - mówiono o nim jako o najdrożej na świecie opłacanym „chórze”. Podstawę tej skromnej analizy stanowią biogramy posłów do Reichstagu zamieszczone w specjalnych wydawnictwach poświęconych tej instytucji, zob. Reichstag-Handbuch VI. Wahlperiode 1932, Berlin 1932; Reichstag-Handbuch IX. Wahlperiode 1933, Berlin 1934; Der Deutsche Reichstag 1936 III. Wahlperiode nach dem 30. Januar 1933, Berlin 1936; Der Großdeutsche Reichstag 1938 IV. Wahlperiode (nach dem 30. Januar 1933), Berlin 1938 oraz Der Grossdeutsche Reichstag. IV. Wahlperiode, beginn am 10. April 1938 verlängert bis zum 30. Januar 1947, Berlin 1943.

${ }^{3}$ Nie próbowałem precyzować ram geograficznych, gdyż byłoby to chyba niemożliwe do wykonania - wiek XIX to przecież czas powstawania nowoczesnych narodów (w tym także narodu polskiego), rodzenia się nacjonalizmów — zmieniał się (w porównaniu chociażby do 1772 roku) zasięg i liczba ludności polskiej, wystarczy wspomnieć tylko o Górnym Śląsku, który z formalno-prawnego punktu widzenia od czasów średniowiecza nie był związany z Polską, a w którym w XIX i XX wieku „narodziła” się polskość. 
wyczerpują problematyki - właściwych źródeł jest ogrom (nade wszystko akta osobowe nazistów), są raczej skromnym zarysowaniem „możliwych” kontaktów, niejako „drogowskazem” i zachętą do dalszych badań szczegółowych, opartych na materiałach archiwalnych. Przystępując do badania tego problemu, oprócz samej ciekawości poznania owych kontaktów, interesowały mnie właściwie dwie kwestie: (1) jaki był charakter owych „spotkań” przyszłych prominentów nazistowskich, czy ich pierwsze kontakty miały charakter „pokojowy”, były wynikiem koegzystencji polsko-niemieckiej (np. narodziny i dojrzewanie na ziemiach bezspornie polskich lub terenach pogranicza), czy może od początku „zetknięcie” z polskością było świadomie ,wrogie”?; oraz (2) czy kontakty z szeroko pojętą polskością miały wpływ na późniejsze kariery prominentów nazistowskich, choćby w okupowanej przez Niemców Polsce (Generalne Gubernatorstwo, ziemie wcielone do Rzeszy)? Spróbowałem uchwycić rzeczone kontakty/spotkania „problemowo”, tj. spojrzeć na nie pod kątem urodzenia, życia w danym miejscu do roku 1918, życia w danym miejscu w okresie międzywojennym (1918-1933), udziału w I wojnie światowej na ziemiach polskich, udziału w walkach polsko-niemieckich w latach 1918-1921 czy posiadania przez dane jednostki polsko brzmiących nazwisk.

\section{Urodzenie}

Wielu przyszłych prominentów nazistowskich przyszło na świat albo na terenach dawnej Rzeczypospolitej Obojga Narodów albo na terenach pogranicza, gdzie krzyżowały się wpływy polskie i niemieckie. Oczywiście miejsce urodzenia nie musiało automatycznie oznaczać, że z całą pewnością wchodzili oni w kontakt z Polakami, z polskością, ale w wielu wypadkach faktycznie tak było, o czym mogą poświadczać ich późniejsze losy i działania. Na terenie dawnego zaboru pruskiego przyszli na świat SS-Obergruppenführer oraz Gauleiter i Reichstatthalter Kraju Warty* Arthur Greiser (ur. 22 stycznia 1897 w Środzie Wielkopolskiej); SS-Gruppenführer i generał-porucznik policji oraz Wyższy Dowódca SS i Policji w Stuttgarcie Kurt Kaul (ur. 5 października 1890 w Brodowie w Wielkopolsce), SA-Obergruppenführer i dowódca SA-Gruppe Ostmark Arno Manthey (ur. 6 września 1888 w Szubinie w Wielkopolsce); Gauhauptamtsleiter NSDAP w Brandenburgii SS-Standartenführer Karl Schultz (ur. 6 lipca 1902 w Poznaniu); nazistowski specjalista od spraw rolnictwa, SS-Standartenführer w Głównym Urzędzie SS ds. Rasy i Osadnictwa Helmut Reinke (ur. 23 marca 1897 w Pyrzynach, w powiecie Gorzów Wielkopolski); SS-Oberführer związany w latach okupacji z Krajem Warty Ulrich Uhle (ur. 21 maja 1897 w Gorzewie

* Przed nazwiskiem danego przywódcy narodowosocjalistycznego starałem się podać najwyższe lub najbardziej prestiżowe stanowiska/funkcje oraz stopień służbowy (NSDAP, SS, SA etc.) dla lepszej orientacji Czytelnika. 
w Wielkopolsce); SA-Brigadeführer Erhard von Schmidt (ur. 2 kwietnia 1903 w Toruniu); SS-Obersturmbannführer, Kreisleiter Słupska i zastępca Gauleitera NSDAP Pomorza Arthur Kauffmann (ur. 10 grudnia 1897 w Dźwierznie, powiat toruński); nazistowski radny Berlina oraz tamtejszy Kreisleiter Hans Fink (ur. 18 grudnia 1898 w Gorzowie Wielkopolskim); działacz NSDAP w Berlinie Karl Bombach (8 lipca 1891 w Skwierzynie w Wielkopolsce) ${ }^{4}$. Można dodać jeszcze takie nazwiska jak emerytowany podpułkownik, działacz NSDAP (Reichsredner) Georg Ahlemann (ur. 8 lutego $1870 \mathrm{w}$ Krotoszynie); funkcjonariusz Gauleitung NSDAP w Berlinie Erich Akt (ur. 3 lipca 1898 w Krotoszynie); kierownik Niemieckiego Frontu Pracy (DAF) w Gau Essen Fritz Johlitz (ur. 23 marca 1898 w Pile); działacz NSDAP w Gau Berlin, RAD-Generalarbeitsführer Hermann Kretzschmann (15 października 1886 w Gorzowie Wielkopolskim); działacz NSDAP (posiadacz Goldenes Ehrenzeichen der NSDAP) i Hitlerjugend (HJ-Obergebietsführer) Werner Kuhnt (ur. 9 czerwca 1911 w Ostrowie Wielkopolskim); Kreisleiter NSDAP Kreis X w Berlinie Karl Wollenberg (ur. 30 kwietnia 1903 w Bartodziejach koło Bydgoszczy — dziś dzielnica tego miasta); Reichsamtsleiter w Hauptamt für Beamte Fritz Tiebel (ur. 6 sierpnia 1889 w Połajewie w Wielkopolsce); SS-Gruppenführer i generał-porucznik policji, dowódca Policji Porządkowej (Inspekteur der Ordnungspolizei) w Dreźnie, następnie w Protektoracie Czech i Moraw (Befehlshaber der Ordnungspolizei) Ernst Hitzegrad (ur. 26 grudnia 1889 we Wschowej); SS-Oberführer i nadburmistrz Neuruppin Kurt Krüger (ur. 16 maja 1894 w Bydgoszczy $)^{5}$. W Wielkopolsce przyszło na świat dwóch innych oficerów

4 Der Grossdeutsche Reichstag. IV. Wahlperiode, beginn am 10. April 1938 verlängert bis zum 30. Januar 1947, Berlin 1943 (dalej jako Gr1943), biogram Arthura Greisera, s. 221 oraz C. Łuczak, Arthur Greiser hitlerowski władca w Wolnym Mieście Gdańsku i w Kraju Warty, Poznań 1997, s. 3. Wedle C. Łuczaka, Greiser miał wielokrotnie chlubić się urodzeniem w Poznańskiem, a 20 grudnia 1942 wypowiedział znamienne słowa: „Jestem dzieckiem tej ziemi i przyznaję się do tego z dumą”; Gr1943, biogram Curta Kaula, s. 264; Der Großdeutsche Reichstag 1938 IV. Wahlperiode (nach dem 30. Januar 1933), Berlin 1938 (dalej jako Gr1938), biogram Arno Mantheya, s. 309; Gr1943, biogram Karla Schultza, s. 382; Gr1943, biogram Helmuta Reinke, s. 345; Gr1943, biogram Ulricha Uhle, s. 411; Der Deutsche Reichstag 1936 III. Wahlperiode nach dem 30. Januar 1933, Berlin 1936 (dalej jako Gr1936), biogram Erharda von Schmidta, s. 293; Gr1936, biogram Arthura Kauffmanna, s. 201; Gr1936, biogram Hansa Finka, s. 145; Gr1943, biogram Karla Bombacha, s. 166.

5 Gr1943, biogram Georga Ahlemanna, s. 144; Gr1943, biogram Ericha Akta, s. 145; Gr1943, biogram Fritza Johlitza, s. 257; Gr1943, biogram Hermanna Kretzschmanna, s. 279; Gr1943, biogram Wernera Kuhnta, s. 282. Dziennik nazistowski w Kraju Warty „Ostdeutscher Beobachter” napisał, iż „Der Reichsjugendführer hat den Führer des Gebietes Mark Brandenburg, Gebietsführer Werner Kuhnt, M.d.R., der selbst ein gebürtiger Posener ist [wyróżnienie moje W.K.], mit dem Aufbau der Hitler-Jugend im Warthe-Gau beauftragt", Unsere Jugend tritt an. Die Hitler-Jugend ruft alle deutschen Jungen und Mädel, „Ostdeutscher Beobachter” nr 1, 1 listopada 1939, s. 9. W innym artykule (zob. Werner Kuhnt wieder Obergebietsführer, „Ostdeutscher Beobachter" nr 139, 21 maja 1942) napisano, że po zajęciu Wielkopolski przez władze polskie Kuhnt z rodzicami wyemigrował do Brandenburgii; Gr1943, biogram Karla Wollenberga, s. 434; Gr1943, biogram Fritza Tiebela, s. 408; o Hitzegradzie A. Schulz, G. Wegmann, D. Zienke, Die Generale der Waffen-SS und der Polizei. Die militärische Werdegänge der Generale, sowie der Ärzte, Veteri- 
SS: SS-Obergruppenführer i generał Waffen-SS oraz szef SS-Führungshauptamtu Hans Jüttner (ur. 2 marca 1894 w miejscowości Śmigiel) oraz SS-Brigadeführer i generał-major policji zajmujący się sprawami Volksdeutschów w SS-Volksdeutsche Mittelstelle Horst Hoffmeyer (ur. 29 maja 1903 w Poznaniu) ${ }^{6}$. Na terenie byłego zaboru rosyjskiego przyszli na świat SS-Standartenführer Ludwik Wolff (ur. 4 sierpnia 1908 w Pabianicach) czy Alexander baron von Wrangell (ur. 10 listopada 1896 w Ostrołęce). Von Wrangell to ciekawa postać - wyznania ewangelickiego, był Niemcem bałtyckim, od urodzenia poddanym rosyjskim; uczęszczał do szkoły średniej w Rewalu, później studiował w Moskwie, następnie w Rydze, po 1918 roku żył i pracował w Niemczech w Gorzowie Wielkopolskim (od 1924 Reichsdeutsch) $)^{7}$. Z terenów Łodzi pochodził przyszły dowódca SA w tym mieście, SA-Oberführer Wilhelm Kretschmar, łódzki volksdeutsch ${ }^{8}$. W Warszawie przyszedł na świat SS-Oberführer Günther Claassen (ur. 1 grudnia 1888), późniejszy tamtejszy prezydent policji w czasie niemieckiej okupacji ${ }^{9}$. W Galicji, a konkretniej w Stanisławowie, urodził się 2 października 1902 roku SS-Oberführer, pracujący w Reichsleitung NSDAP w Monachium jako Reichsamtsleiter, a od 1940 zastępca Gauleitera Gau Oberdonau z siedzibą w Linzu Christian Opdenhoff ${ }^{10}$.

Na Śląsku urodziło się wielu znaczących nazistów. Wrocław był miejscem urodzenia takich postaci, jak prezydent policji we Wrocławiu od 1934, prezydent rejencji opolskiej, SS-Brigadeführer Albrecht Schmelt (ur. 19 sierpnia 1899); dowódca NSKK na Śląsku NSKK-Obergruppenführer Heinrich-Christian Schäfer-Hansen (ur. 31 stycznia 1901); długoletni działacz nazistowski na Śląsku (Untergauleiter NSDAP Schlesien) i burmistrz Szklarskiej Poręby Richard Türk (ur. 28 marca 1903); działacz śląskiej NSDAP Gustav Adolf Kulisch (ur. 20 kwietnia 1903); dowódca Waffen-SS w Protektoracie Czech i Moraw SS-Gruppenführer i generał-porucznik Waffen-SS Carl hrabia von Pückler-Burghauss (ur. 7 października 1886); Kreisleiter NSDAP i starosta w Lüdinghausen (Westfalia) Herbert Barthel (ur. 24 sierpnia 1895); związany z NSDAP od lat 20., współtwórca, wraz z Kurtem Daluege, SA w Berlinie, SA-Gruppenführer, po 1939 przywódca Technische Nothilfe dla Dolnego i Górnego Śląska Waldemar Geyer (ur. 14 marca 1882); działacz wrocławskiej NSDAP i SA-Obersturmbannführer Ernst Jenke (ur. 27 lutego 1883); działacze NSDAP (o których będzie mowa w dalszej części) Georg Joschke (ur. 6 kwietnia 1900) czy Bruno Müller-Reinert (ur. 20 kwietnia 1897); działacz

näre, Intendanten, Richter und Ministerialbeamten im Generalsrang, t. 2, Bissendorf 2005, s. 286; o Krügerze ibidem, s. 277.

${ }^{6}$ Ibidem, s. 314, 386.

7 Gr1943, biogram Ludwika Wolffa, s. 433; Gr1943, biogram Alexandra barona von Wrangella, s. 309.

8 M. Cygański, Z dziejów okupacji hitlerowskiej w Łodzi, Łódź 1965, s. 140.

9 A. Schulz, G.Wegmann, D. Zienke, op. cit., s. 101.

10 Gr1943, biogram Christiana Opdenhoffa, s. 319. 
śląskiej, a później dolnośląskiej NSDAP i SA-Standartenführer Dr med. Karl Peschke (ur. 12 września 1882); przywódca Niemieckiego Frontu Pracy w Gau Berlin Alfred Spanenberg (ur. 21 lipca 1897); Reichsredner NSDAP i burmistrz Chojnowa Paul Franke (ur. 27 kwietnia 1892) ${ }^{11}$. W okolicach Wrocławia urodzili się Erich Hasse (ur. 31 października 1897 w Kobierzycach w powiecie wrocławskim); Reichsamtsleiter NSDAP Berthold Karwahne (ur. 3 października 1887 w Kobierzycach w powiecie wrocławskim); zastępca przywódcy Narodowosocjalistycznego Korpusu Lotników Dr rer. pol. Günther Ziegler (ur. 9 lutego 1892 w Leśnicy koło Wrocławia - dziś dzielnica tego miasta); SA-Standartenführer Paul Schmidt (ur. 19 sierpnia $1901 \mathrm{w}$ Olbrachtowicach w powiecie wrocławskim) ${ }^{12}$. Na Dolnym Śląsku urodzili się także Hans Hayn (ur. 7 sierpnia 1896 w Legnicy); działacz NSDAP w Turyngii, SA-Obergruppenführer oraz premier Turyngii, minister finansów, gospodarki i oświaty w tym landzie Willy Marschler (ur. 12 sierpnia 1893 w Legnicy); SS-Obergruppenführer Udo von Woyrsch (ur. 24 lipca 1895 w Zwanowicach); Gauleiter NSDAP okręgu śląskiego Hellmuth Brückner (ur. 7 maja 1896 w Piławie, w powiecie dzierżoniowskim); działacz śląskiej NSDAP (od 1934 Kreisleiter NSDAP we Wrocławiu) i SA-Sturmbannführer Walter Hamfler (ur. 22 lipca 1907 w Rudnej); działacz NSDAP w Kłodzku i poseł do Reichstagu Paul Geburtig (ur. 18 września 1896 w Kuźnicach Świdnickich); Kreisbauernführer NSDAP na Śląsku Paul Hoenscher (ur. 25 marca 1887 w Nowej Wsi Małej); Gauleiter NSDAP w Brandenburgii oraz Komisarz Rzeszy na Białorusi Wilhelm Kube (ur. 13 listopada 1887 roku w Głogowie); działacz NSDAP w Kłodzku i poseł do Reichstagu Georg Neugebauer (ur. 14 stycznia 1901 w Kłodzku); Hans Ramshorn (ur. 17 marca 1892 w Międzylesiu w powiecie Bystrzyca Kłodzka); Kreisleiter NSDAP Oleśnicy, a później specjalista ds. wschodnich w Gau Schlesien NSDAP oraz przywódca Bund Deutscher Osten na Śląsku Wolfgang hrabia Yorck von Wartenburg (ur. 9 września 1899 w Śliwicach w powiecie oleśnickim); działacz w Gau Niederschlesien NSDAP (RAD-Gauarbeitsführer) Günther Arndt (ur. 1 grudnia 1894 w Łomnicy w powiecie jeleniogórskim); Kreisleiter NSDAP w Głogowie, Gauredner Karl Brückner (ur. 11 czerwca 1904 w Dolnej Wsi koło Nysy); Kreisleiter NSDAP w Bolkowie Emil Engler (ur. 15 września 1895 w Bolkowie); Heinrich Georg hrabia Fink von Finkenstein (ur. 22 listopada 1894 w miejscowości

11 Gr1943, biogram Albrechta Schmelta, s. 369; Gr1943, biogram Heinricha-Christiana Schäfer-Hansena, s. 362; Gr1943, biogram Richarda Türka, s. 410; Reichstag-Handbuch IX. Wahlperiode 1933, Berlin 1934 (dalej jako Gr1933), biogram Gustava Adolfa Kulischa, s. 241; Gr1933, biogram Carla hrabiego von Pückler-Burghaussa, s. 226; Gr1943, biogram Herberta Barthela, s. 152; Gr1943, biogram Waldemara Geyera, s. 215; Gr1943, biogram Ernesta Jenke, s. 256; Gr1943, biogram Georga Joschke, s. 259; Gr1943, biogram Brunona Müller-Reinerta, s. 308; Gr1943, biogram dr Karla Peschke, s. 324; Gr1943, biogram Alfreda Spanenberga, s. 394; Gr1943, biogram Paula Franke, s. 208.

12 Reichstag-Handbuch VI. Wahlperiode 1932, Berlin 1932 (dalej jako Gr1932), biogram Ericha Hasse, s. 91; Gr1943, biogram Bertholda Karwahne, s. 263; Gr1933, biogram dr Günthera Zieglera, s. 313; Gr1943, biogram Paula Schmidta, s. 372. 
Żelazno w powiecie kłodzkim); w latach 30. dowódca SS i SA na Śląsku (jako SA-Brigadeführer), a od 1943 prezydent policji w Lipsku SS-Brigadeführer i generał major policji Wilhelm von Grolman (ur. 16 lipca 1894 w Świdnicy); jeden z najbliższych współpracowników Goebbelsa po 1933 roku w Ministerstwie Propagandy i Oświecenia Ludowego Rzeszy (sekretarz stanu), po 1941 Gauleiter Gau Niederschlesien i nadprezydent prowincji Niederschlesien, SS-Obergruppenführer (w nagrodę za wierność i nieustępliwość mianowany Reichsführerem-SS przez Hitlera w ostatnich dniach Rzeszy) Karl Hanke (ur. 24 sierpnia 1903 w Lubaniu); działacz NSDAP w Gau Hessen-Nassau (Gauinspekteur. Gaupersonalamtsleiter, Reichsredner) Walther Heyse (ur. 17 czerwca 1902 w Pasikurowicach); Landesbauernführer Gau Schlesien, SS-Standartenführer Otto Jaeschke (ur. 17 listopada 1890 w Brodowie); działacz śląskiej NSDAP: Kreisbauernführer w Dzierżoniowie Fritz Marx (ur. 27 kwietnia 1900 w Sobótce); Kreisleiter NSDAP Kreis I Groß-Berlin, przywódca Bund heimattreuer Schlesier (Vereinigte Oberschlesier und Schlesier) Paul Skoda (ur. 29 czerwca 1901 w Schnellau, dziś dzielnica Kudowy-Zdroju); Georg Tesche (ur. 28 grudnia 1901 w Żarowie); SS-Standartenführer i prezydent policji w Bydgoszczy (rozstrzelany pod koniec stycznia 1945 przez SS za tchórzostwo i zaniedbywanie obowiązków służbowych) Karl-Otto von Salisch (ur. 28 listopada 1902 w Głogowie); SA-Brigadeführer Peter Vogt (ur. 15 czerwca 1897 w Maliniku koło Jeleniej Góry); Gauredner Gau Schlesien Konrad Ritsch (ur. 16 listopada 1906 w Dworku na Śląsku) ${ }^{13}$.

Górny Śląsk był terenem, gdzie jeszcze intensywniej krzyżowały się wpływy niemiecko-polskie — tu urodzili się między innymi Kreisleiter NSDAP w Bytomiu po 1935 Ernst Mutz (ur. 19 sierpnia 1900 w Gliwicach), Kreisleiter NSDAP w Bytomiu w latach 1933-1935, później Kreisleiter Kluczborka Johannes Schweter (ur. 29 sierpnia 1901 w Szombierkach, dziś dzielnica Bytomia); dr Fritz Kleiner (ur. 6 maja 1893 w Bytomiu); dr med. Gerhard Wagner (ur. 18 sierpnia 1888 w Hajdukach Nowych, dziś Chorzów); Paul Binus (ur. 13 sierpnia 1901 w Raciborzu); Max Fillusch (ur. 9 grudnia 1896 w Warmątowicach nieopodal Kędzierzyna-Koźle); SA-Brigadeführer Wilhelm Heerde (ur. 21 września 1898

13 Gr1933, biogram Hansa Hayna, s. 196; Gr1943, biogram Willego Marschlera, s. 296; Gr1943, biogram Udona von Woyrscha, s. 435; Gr1933, biogram Helmutha Brücknera, s. 145; Gr1938, biogram Waltera Hamflera, s. 236; Gr1933, biogram Paula Geburtiga, s. 178; Gr1936, biogram Paula Hoenschera, s. 186; Gr1933, biogram Wilhelma Kubego, s. 240; Gr1933, biogram Georga Neugebauera, s. 213; Gr1933, biogram Hansa Ramshorna, s. 281; Gr1933, biogram Wolfganga hrabiego Yorck von Wartenburg, s. 374; Gr1943, biogram Günthera Arndta, s. 147; Gr1943, biogram Karla Brücknera, s. 172; Gr1943, biogram Emila Englera, s. 196; Gr1943, biogram Heinricha Georga hrabiego Fink von Finkensteina, s. 203; Gr1943, biogram Wilhelma von Grolmana, s. 223; Gr1943, biogram Karla Hanke, s. 231; Gr1943, biogram Walthera Heyse, s. 241; Gr1943, biogram Otto Jaeschke, s. 254; Gr1943, biogram Fritza Marxa, s. 297; Gr1943, biogram Paula Skody, s. 392; Gr1943, biogram Georga Tesche, s. 406; O von Salischu zob. A. Schulz, G. Wegmann, D. Zienke, op. cit., s. 150 oraz D. Schenk, Albert Forster gdański namiestnik Hitlera. Zbrodnie hitlerowskie w Gdańsku i Prusach Zachodnich, Gdańsk 2002, s. 363-364; Gr1933, biogram Petera Vogta, s. 354; Gr1933, biogram Konrada Ritscha, s. 290. 
w Prudniku); Alfred Jonas (ur. 22 czerwca 1903 w Opolu); Alfred Karrasch (ur. 26 stycznia 1889 w Opolu); działacz śląskiej NSDAP i SA-Obersturmbannführer, a po 1941 funkcjonariusz partyjny Gau Oberschlesien w Katowicach Erwin Schramm (ur. 6 lipca 1910 w Krapkowicach koło Opola); działacz śląskiej NSDAP (1931-1932 Untergauleiter Untergau Mittelschlesien NSDAP oraz do marca 1933 Kreisleiter NSDAP Breslau-Stadt), w latach 1933-1940 nadburmistrz Wrocławia SS-Obersturmbannführer Josef Schönwälder (ur. 13 lipca 1897 w Jędrzejowie koło Grodkowa); Richard Preiss (ur. 18 kwietnia 1902 w Wojnowicach w powiecie głubczyckim); w latach 1936-1941 Gaugeschäftsführer w Gau Schlesien, a od 1941 Gaustabsamtsleiter Gau Oberschlesien w Katowicach Paul Roden (ur. 1 października 1902 w Chrzelicach); Kreisleiter NSDAP w Raciborzu Alfred Hawellek (ur. 20 stycznia 1905 w Raciborzu); działacz śląskiej NSDAP (Gaupropagandaleiter, następnie Untergauleiter Niederschlesien od 1932, Gauinspekteur), burmistrz Złotoryi i SA-Oberführer Walter Gottschalk (ur. 10 listopada 1893 w Leśnicy w powiecie Strzelce Opolskie); działacz NSDAP na Opolszczyźnie, Landesbauernführer w Opolu Johannes Slawik (ur. 23 stycznia 1892 w Krzanowicach w powiecie raciborskim); działacz górnośląskiej NSDAP Erich Russek (ur. 8 czerwca 1893 w Zabrzu); SS-Standartenführer, doradca śląskiej NSDAP ds. rolnictwa, Landesbauernführer Gau Schlesien Johannes baron von Reibnitz (ur. 23 października 1882 w Łanach na Górnym Śląsku); działacz śląskiej NSDAP (Untergauleiter Gau Schlesien) i starosta (Landeshauptmann) prowincji Schlesien SS-Oberführer Josef Joachim Adamczyk (Adams) (ur. 20 marca 1901 w Rzuchowie) ${ }^{14}$. Przyszły SS-Oberst-Gruppenführer i szef Orpo oraz p.o. Protektora Rzeszy Czech i Moraw po śmierci Heydricha Kurt Daluege urodził się 15 września 1897 w Kluczborku ${ }^{15}$. W Lublińcu przyszedł na świat (ur. 27 maja 1879) SS-Obergruppenführer, Reichsminister oraz Chef der Reichskanzlei Dr Hans Heinrich

14 Gr1943, biogram Ernsta Mutza, s. 311; Gr1943, biogram Johannesa Schwetera, s. 386; Gr1936, biogram dr Fritza Kleinera, s. 206; Gr1938, biogram dr med. Gerharda Wagnera, s. 441; Gr1943, biogram Paula Binusa, s. 159; Gr1943, biogram Maxa Filluscha, s. 202; Gr1943, biogram Wilhelma Heerde, s. 234; Gr1943, biogram Alfreda Jonasa, s. 257; o Karraschu, zob. A. Schulz, G. Wegmann, D. Zienke, op. cit., s. 469; Gr1943, biogram Erwina Schramma, s. 377; Gr1943, biogram Josefa Schönwäldera, s. 376; Gr1943, biogram Richarda Preissa, s. 334; Gr1943, biogram Paula Rodena, s. 352; Gr1943, biogram Alfreda Hawellka, s. 233; Gr1943, biogram Waltera Gottschalka, s. 220; Gr1943, biogram Johannesa Slawika, s. 330; Gr1943, biogram Ericha Russka, s. 297; Gr1938, biogram Johannesa barona von Reibnitz, s. 353; Gr1933, biogram Josefa Joachima Adamczyka, s. 124.

15 Gr1943, biogram Kurta Daluege, s. 181. Napisano o Daluege w górnośląskim wydawnictwie periodycznym: „Zu den Männern, die als nächste Mitarbeiter des Führers seit vielen Jahren den Aufstieg der Bewegung und die Geschicke des Großdeutschen Reiches mitgestalten, gehören [...] SS-Oberstgruppenführer und Generaloberst der Polizei Kurt Daluege aus Kreuzburg (geb. 1897), der als stellvertretender Reichsprotektor seit Juni 1942 die Hoheit des Reiches in Prag ausübt", zob. E. Boberski, Grosse Deutsche aus Oberschlesien, „Oberschlesischer Heimatkalender für das Jahr” 1943, s. 130. 
Lammers ${ }^{16}$. W Pszczynie urodził się w 1862 roku żarliwy nacjonalista i nazista, SS-Oberführer Karl Hoefer ${ }^{17}$.

Kolejnym terenem pogranicza było Pomorze. Tu przyszli na świat: jeden z najważniejszych dowódców SS i współpracowników Himmlera w okresie dominacji SA nad SS, SS-Gruppenführer i Chef des SS-Stabes Siegfried Seidel-Dittmarsch (ur. 4 stycznia 1887 w Pomieniu w powiecie Choszczno); późniejszy Wyższy Dowódca SS i Policji na Śląsku, w Związku Sowieckim (Russland-Mitte), dowódca jednostek zwalczających partyzantów, dowódca jednostek niemieckich w Powstaniu Warszawskim, bliski współpracownik RFSS Erich von dem Bach-Żelewski (ur. 1 marca 1899 w Lęborku); Kreisleiter NSDAP we Frankfurcie nad Odrą i poseł do Reichstagu Martin Albrecht (ur. 26 grudnia 1893 w Oruni, dziś dzielnica Gdańska); działacz nazistowski (SA, DAF) w Hamburgu Friedrich Boschmann (ur. 1 stycznia 1903 w Płonii Wielkiej koło Gdańska); związany z NSDAP w Gdańsku: od 1933 jako Landesbauernführer Gau Danzig, od 1934 jako kierownik Amt für Agrarpolitik Gau Danzig, od 1934 senator w Senacie Wolnego Miasta Gdańska do spraw rolnictwa, leśnictwa i weterynarii, SS-Oberführer Lothar Rethel (ur. 3 marca 1895 w Suchym Dębie w powiecie gdańskim); Kreisleiter NSDAP w Lęborku oraz przewodniczący tamtejszej rady miejskiej Willy Fruggel (ur. 7 listopada 1885 w Ługach w powiecie lęborskim); Hans Peter von Heydebreck (ur. 1 lipca 1889 w Koszalinie); jeden z twórców NSDAP w Szczecinie Hans Grüneberg (ur. 7 października 1899 w Świnoujściu); SS-Gruppenführer (m.in. Chef des Führungsamtes w SS-Hauptamt) Karl Zech (ur. 6 lutego 1892 w Świnoujściu); działacz NSDAP w Gau Pommern (Gauorganisationsleiter, a później komendant NS-Ordensburg. „Die Falkenburg am Krössinsee”) i SA-Brigadeführer Otto Gohdes (ur. 17 grudnia 1896 w Złocieńcu); jeden z bliskich współpracowników Himmlera (m.in. Chef SS-Hauptamt Volksdeutsche Mittelstelle) SS-Obergruppenführer Werner Lorenz (ur. 2 października 1891 w Wykrotach koło Słupska); Kreisleiter NSDAP w Nowogardzie, Landesbauernführer Gau Pommern NSDAP SS-Standartenführer Kurt Lüdtke (ur. 18 września 1898 w Nowogardzie); Kreisleiter NSDAP w Mannheim w latach 1928-1930, po 1931 dowódca HJ w Badenii Friedhelm Kemper (ur. 24 listopada 1906 w Pyrzycach); SA-Brigadeführer Carl Ludwig Schleich (ur. 3 kwietnia 1899 w Piątkowie w powiecie chełmskim); Gauamtsleiter für Agrarpolitik w Gau Pommern NSDAP i tamtejszy Landesbauernführer SA-Brigadeführer Willi Bloedern (ur. 6 kwietnia 1887 w Kukułowie w powiecie Kamień); Gaugeschäftsführer Gau NSDAP Brandenburg Erich Schmiedicke (ur. 13 maja 1887 w Szczecinku); Kreisleiter Szczecinka od 1930 Fritz Kohls (ur. 8 października 1894 w Marcelinie); Bruno Czarnowski (później Scharno) (ur. 15 kwietnia 1902 w Grudziądzu); Kreisleiter NSDAP w Marburgu po 1933 i starosta Hans Krawielitzki (ur. 26 listopada 1900 w Więcborku); Felix Piékarski

16 D. Rebentisch, Lammers Hans Heinrich, [w:] Neue Deutsche Biographie, t. 13, Berlin 1982, s. 449.

17 E. Boberski, op. cit., s. 132. 
(ur. 10 lipca 1890 w Grucznie); oficer SA (SA-Brigadeführer) i SS (SS-Brigadeführer i generał-major policji), Dowódca SS i Policji w Kownie Lutz Wysocki (ur. 18 stycznia 1899 w Gętomiach); działacz wschodniopruskiej NSDAP: Kreisleiter NSDAP w Kwidzyniu, od 1934 Kreisleiter NSDAP i starosta w Heiligenbeil Otto Schmidtke (ur. 8 sierpnia 1902 w Prabutach) ${ }^{18}$. Ponadto w Gdańsku urodzili się Senator ds. Zdrowia w Senacie Wolnego Miasta Gdańska, Gauamtsleiter für die Volksgesundheit Gau NSDAP Danzig, SS-Standartenführer prof. dr med. Hellmuth Kluck (ur. 25 września 1894) oraz jego następca na wymienionych stanowiskach SS-Standartenführer dr med. Erich Grossmann (ur. 30 stycznia 1902), który piastował rzeczone funkcje do $1945 \mathrm{roku}^{19}$. W Szczecinie urodzili się Hans Kammler (ur. 26 sierpnia 1901) oraz SS-Brigadeführer i generał-major Waffen-SS Fritz Kraemer (ur. 12 grudnia 1900), zaś w Kwidzyniu SS-Brigadeführer i generał-major Waffen-SS dr med. Gustav Karehnke (ur. 15 lipca 1895) czy szef Amtsgruppe B w SS-FHA, SS-Obergruppenführer i generał Waffen-SS Kurt Knoblauch (ur. 10 grudnia 1885$)^{20}$.

W Prusach Wschodnich po raz pierwszy ujrzeli swiatło dzienne: minister gospodarki Rzeszy Walther Funk (ur. 18 sierpnia 1890 w Trakehnen) ${ }^{21}$; Gauleiter NSDAP Gau Mark Brandenburg oraz nadprezydent Brandenburgii Emil Stürtz (ur. 15 listopada 1892 w Wiebs w powiecie olsztyńskim); SS-Oberstgruppenführer, Najwyższy Dowódca SS i Policji (HöSSPF) na Ukrainie, bliski współpracownik RFSS i jeden z największych zbrodniarzy w SS Hans Adolf Prützmann (ur. 31 sierpnia $1901 \mathrm{w}$ Tolkmicku w powiecie elbląskim); prezydent rejencji ciechanowskiej oraz jeden z najbliższych współpracowników Gauleitera Ericha Kocha Paul Dargel (ur. 28 grudnia 1903 w Elblągu); związany

18 Gr1933, biogram Siegfrieda Seidel-Dittmarscha, s. 326; Gr1943, biogram Ericha von dem Bach-Żelewskiego, s. 149; Gr1933; biogram Martina Albrechta, s. 125; Gr1943, biogram Friedricha Boschmanna, s. 168; Gr1943, biogram Lothara Rethela, s. 348; Gr1933, biogram Willy'ego Fruggela, s. 176; Gr1933, biogram Hansa Petera von Heydebrecka, s. 205; Gr1943, biogram Hansa Grüneberga, s. 225; Gr1943, biogram Karla Zecha, s. 437; Gr1943, biogram Ottona Gohdesa, s. 219; Gr1943, biogram Wernera Lorenza, s. 292 ; Gr1943, biogram Kurta Lüdtke, s. 293; Gr1943, biogram Friedhelma Kempera, s. 265; Gr1943, biogram Carla Ludwiga Schleicha, s. 367; Gr1943, biogram Williego Bloederna, 161; Gr1933, biogram Ericha Schmiedecke, s. 251; Gr1932, biogram Fritza Kohlsa, s. 132; Gr1943, biogram Bruno Scharno (Czarnowskiego), s. 363; Gr1943, biogram Hansa Krawielitzkiego, s. 277; Gr1943, biogram Felixa Piékarskiego, s. 328; Gr1943, biogram Lutza Wysockiego, s. 436; Gr1943, biogram Ottona Schmidtke, 372;

19 A. Schulz, G.Wegmann, D. Zienke, op. cit., s. 47.

20 Ibidem, s. 441-443, 465, 534, 587.

${ }^{21}$ Gr1932, biogram Walthera Funka, s. 268. W czasie pobytu w więzieniu w Spandau Funk miał „odkryć” swoje słowiańskie (polskie?) korzenie. Albert Speer pisał: „Zachęcony przez poufałe zachowanie niektórych Rosjan, Funk odkrył tymczasem słowiańską babkę; nieco później znalazł się także rosyjski cioteczny dziadek i stopniowo, z rosnącą śmiałością, dokonuje genealogicznego przesunięcia na wschód. Schirach skomentował to zjadliwie: »To chyba czysty przypadek, że twoją rodzinę zagnało do Niemiec«. Funk pozostał jednak przy swoim radosnym cynizmie. Pogodnie uderzył się swoim zeszytem z rosyjskimi słówkami w kolano i powiedział: »Idę się teraz trochę pouczyć ojczystego języka«", A. Speer, Dzienniki ze Spandau, Warszawa 2010, s. 347. 
z NSDAP już od 1921, jeden z założycieli SA w Prusach Wschodnich, wysoko postawiony działacz NSDAP w Prusach Wschodnich, jeden z najbliższych współpracowników Ericha Kocha, SA-Oberführer Waldemar Magunia (ur. 8 grudnia 1902 w Królewcu); SS-Standartenführer w Dreźnie Georg Schroeder (ur. 3 kwietnia 1898 w Królewcu); SA-Brigadeführer w Prusach Wschodnich Erwin Nötzelmann (ur. 14 marca 1907 w Królewcu); NSFK-Obergruppenführer i Gaurichter w Gau Ostpreußen Ewald Oppermann (ur. 25 lutego 1896 w Królewcu); SA-Brigadeführer Eugen Plorin (ur. 8 października 1901 w Królewcu); Kurt Kühme (ur. 27 sierpnia 1885 w Giżycku); działacz wschodniopruskiej NSDAP (m.in. Gauamtsleiter für Volkswohlfahrt) Erich Fuchs (ur. 23 maja 1894 w Insterburgu); przywódca Niemców z Kłajpedy i SS-Oberführer dr Ernst Neumann (ur. 13 lipca 1888 w Wężówce w powiecie giżyckim); SA-Oberführer Hermann Paltinat (ur. 23 października 1905 w Oschke w powiecie Niederung); funkcjonariusz NSDAP w Gau Ostpreußen (Gaupropagandaleiter i kierownik Reichspropagandaamt Ostpreußen) Joachim Paltzo (ur. 11 stycznia 1912 w Rastenburgu, dziś Kętrzyn); piastujący wiele funkcji państwowych i partyjnych w Gau NSDAP Pommern Walther von Corswant (ur. 14 kwietnia 1886 w Gumbinnen); SA-Oberführer przy SA-Gruppe Berlin-Brandenburg oraz radca ministerialny w Ministerstwie Nauki, Wychowania i Kształcenia Rzeszy dr phil. Georg Usadel (ur. 14 marca 1900 w Gumbinnen); SA-Brigadeführer Erich Behrendt (ur. 22 maja 1904 w Srokowskim Dworze w powiecie Rastenburg); działacz NSDAP i poseł do Reichstagu Wilhelm Grezesch (ur. 1 maja 1906 w Nidzicy); SA-Oberführer Karl Jackstien (ur. 14 czerwca 1899 w Gründen, powiat Labiau — dziś Polessk); w latach 20. i 30. działacz nazistowski w Prusach Wschodnich (Gauschatzmeister Gau Ostpreußen, Kreisleiter NSDAP w Królewcu) Ernst Penner (ur. 16 lipca 1883 w Paskallwen); działacz NSDAP w Prusach Wschodnich Waldemar Weißel (ur. 18 lutego 1897 w Wysokiej Braniewskiej); działacz wschodniopruskiej NSDAP (Kreisleiter, Gaukommissar, Gauinspekteur. Gauhauptamtsleiter NS-Volkswohlfahrt) Erich Post (ur. 23 grudnia 1900 w Steffensfelde); działacz wschodniopruskiej NSDAP (kierownik Amt für Beamte NSDAP Gau Ostpreußen) Alfred Preuss (ur. 26 marca 1887 w Czerwonce w powiecie Reszel); jeden z czołowych nazistów w Kłajpedzie, rolnik, SS-Obersturmbannführer Ernst Rademacher (ur. 18 lipca 1903 w Winge w powiecie tylżyckim); Kreisleiter NSDAP i Kreisbauernführer w Gerdauen Fritz Stolz (ur. 2 września 1889 w Kiauken w powiecie Gerdauen $)^{22}$.

22 Gr1943, biogram Emila Stürtza, s. 404; Gr1943, biogram Hansa Adolfa Prützmanna, s. 335; Gr1943, biogram Paula Dargela, s. 182; Gr1943, biogram Waldemara Maguni, s. 295; Gr1943, biogram Georga Schroedera, s. 317; Gr1943, biogram Erwina Nötzelmanna, s. 315; Gr1943, biogram Ewalda Oppermanna, s. 319; Gr1943, biogram Eugena Plorina, s. 330; Gr1943, biogram Kurta Kühme, s. 281; Gr1943, biogram Ericha Fuchsa, s. 213; Gr1943, biogram dr Ernsta Neumanna, s. 314; Gr1943, biogram Hermanna Paltinata, s. 321; Gr1943, biogram Joachima Paltzo, s. 321; Gr1938, biogram Walthera von Corswanta, s. 179; Gr1943, biogram dr Georga Usadela, s. 147; 


\section{Życie do 1918 roku}

Wielu prominentów miało lub mogło mieć kontakt z polskością przez codzienną egzystencję, życie na obszarach dawnej Rzeczypospolitej Obojga Narodów albo na obszarach pogranicza czy takich, gdzie zamieszkiwali Polacy. $\mathrm{Na}$ terenach byłego zaboru pruskiego kształcili się emerytowany podpułkownik armii niemieckiej, który gościnnie znalazł się na liście NSDAP do Reichstagu Otto von Feldmann (nauka w Królewskim Gimnazjum w Bydgoszczy), Hans Fink (szkoła realna w Gorzowie Wielkopolskim); Arthur Kauffmann (szkoła ludowa w Wąbrzeźnie); Arno Manthey (szkoła ludowa w Szubinie, następnie gimnazjum w Bydgoszczy); Georg Ahlemann (gimnazjum realne w Poznaniu); Arthur Greiser (szkoła w Środzie Wielkopolskiej, następnie gimnazjum humanistyczne w Inowrocławiu); Ulrich Uhle (wyższa szkoła realna Hindenburga w Bydgoszczy); kierownik Rassenpolitisches Amt der NSDAP, lekarz, profesor honorowy uniwersytetu berlińskiego dr Walter Gross (gimnazjum humanistyczne w Poznaniu); Fritz Johlitz (szkoła ludowa w Pile); Hermann Kretzschmann (szkoła mieszczańska w Gorzowie Wielkopolskim); Helmut Reinke (szkoła ludowa w Pyrzynach koło Gorzowa Wielkopolskiego); Alfred Spanenberg (gimnazjum w Sulechowie); Alter Kämpfer berlińskiej NSDAP, SS-Brigadeführer Kurt Wege (gimnazjum we Wschowej i w Poznaniu); Carl Ludwig Schleich (szkoła średnia w Poznaniu); Hans Jüttner (szkoła ludowa i gimnazjum Wilhelma w Krotoszynie); Hans Kammler (szkoła w Bydgoszczy, a później gimnazjum miejskie w Gdańsku); Horst Hoffmeyer (miejska wyższa szkoła realna w Bydgoszczy) ${ }^{23}$. Odbywali służbę wojskową: Karl Jackstien (w latach 1917-1919 służył przy Flieger-Ersatz-Abteilung Bromberg w Bydgoszczy); Hans Ramshorn (zaciągnął się do armii pruskiej, w 1910 roku został podporucznikiem w Infanterie-Regiment

Gr1938, biogram Ericha Behredta, s. 156; Gr1932, biogram Wilhelma Grezescha, s. 275; Gr1938, biogram Karla Jackstiena, s. 261; Gr1938, biogram Ernsta Pennera, s. 337; Gr1933, biogram Waldemara Weißela, s. 365; Gr1943, biogram Ericha Posta, s. 333; Gr1943, biogram Alfreda Preussa, s. 334; Gr1943, biogram Ernsta Rademachera, s. 337; Gr1943, biogram Fritza Stolza, s. 401.

${ }^{23}$ Gr1936, biogram Otto von Feldmanna, s. 142; Gr1936, biogram Hansa Finka, 145; Gr1936, biogram Arthura Kauffmanna, s. 201; Gr1938, biogram Arno Mantheya, s. 309; Gr1943, biogram Georga Ahlemanna, s. 144; Gr1943, biogram Arthura Greisera, s. 221 oraz C. Łuczak, op. cit., s. 3, 63. Greiser został wydalony z gimnazjum w Inowrocławiu za agresywne zachowanie wobec kolegów narodowości polskiej i wszczynanie z nimi bójek (Ibidem, s. 4). Autorka najnowszej biografii Greisera, Catherine Epstein, podaje, że Arthur Greiser władał językiem polskim, którego nauczył się w szkole, jednak nie jest jednoznacznie przekonana o antypolskiej postawie Greisera w czasach szkolnych, zob. C. Epstein, Wzorcowy nazista. Arthur Greiser i okupacja Kraju Warty, Wrocław 2011, s. 25-26. Gr1943, biogram Ulricha Uhle, s. 411; Gr1943, biogram dr Waltera Grossa, s. 224; Gr1943, biogram Fritza Johlitza, s. 257; Gr1943, biogram Hermanna Kretzschmanna, s. 279; Gr1943, biogram Helmua Reinke, s. 345; Gr1943, biogram Alfreda Spanenberga, s. 394; Gr1943, biogram Kurta Wege, s. 422; Gr1943, biogram Carla Ludwiga Schleicha, s. 367; Jüttner: A. Schulz, G. Wegmann, D. Zienke, op. cit., s. 387; Kammler: ibidem, s. 442; Hoffmeyer: ibidem, s. 315 ; 
von Borcke/4. Pommersches/Nr 21 w Toruniu, w nim walczył w I wojnie światowej); Georg Ahlemann (wstąpił jako kadet/Fahnenjunker w maju 1889 roku do Feldartillerie-Regiment von Peucker Nr 6 we Wrocławiu; później stacjonował w garnizonach m.in.: Wrocławiu, Szczecinie, Grudziądzu czy Lesznie); Erich von dem Bach-Żelewski (w listopadzie 1914 jako 15-letni ochotnik wstąpił do 9. Westpreußisches Infanterie-Regiment $\mathrm{Nr} 176 \mathrm{w}$ Toruniu, następnie wziął udział w I wojnie m.in. także w 3. Westpreußisches Infanterie-Regiment Nr 129 w Grudziądzu); działacz NSDAP w Gau Berlin i SA-Obersturmbannführer Hans von Freyberg (służba wojskowa m.in. w Königs-Jäger-Regiment zu Pferde w Poznaniu); Ewald Schulz (udział w I wojnie, w 1918 znalazł się we Fliegerschule w Poznaniu, następnie w Pile); dowódca SA i prezydent policji w Recklinghausen SA-Gruppenführer Hans Vogel (w 1914 roku wstąpił jako ochotnik do Regiment Königs-Jäger zu Pferde Nr. 1 w Poznaniu); działacz śląskiej NSDAP zajmujący się rolnictwem, SS-Standartenführer Hermann Schneider (jako 42-latek w sierpniu 1914 roku zgłosił się do Landsturmbataillon w Lesznie/Lissa); Fritz Kohls (w 1912 jako „zweijährig Freiwilliger” służba w 6. Pommersches Infanterie-Regiment $\mathrm{Nr} 49$ w Gnieźnie); jeden z najpotężniejszych i najzdolniejszych dowódców Waffen-SS, emerytowany generał Reichswehry, SS-Oberstgruppenführer i generał pułkownik Waffen-SS Paul Hausser (w latach 1899-1906 służba w Infanterie-Regiment Nr 155, przemianowany w 1902 na 7. Westpreußisches Infanterie-Regiment Nr 155 w Ostrowie Wielkopolskim; wiosną 1908 zdawał w Poznaniu egzamin wstępny do Kriegsakademie w Berlinie); dr med. Gerhard Karehnke (w 1916 kształcił się na obserwatora [Beobachter] w Poznaniu) ${ }^{24}$. Niektórzy bywali urzędnikami, jak Anton Hauk (w latach 1903-1920 urzędnik ds. rolnych [landwirtschaftlicher Beamter] w Prowincji Poznańskiej); Hermann Schneider (wyższy urzędnik [Oberbeamter] w Koźminie Wielkopolskim w Prowincji Poznańskiej oraz przewodniczący tamtejszego Kreisverein); starosta w Giżycku przed 1939 i SS-Sturmbannführer Ernst Speidel (urzędnik rolniczy - landwirtschaftlicher Beamter w Poznaniu, Prusach Zachodnich i Prusach Wschodnich); Arthur Kauffmann (praktykant przy starostwie w Wąbrzeźnie); Hans Fink (praktykant w banku, później urzędnik w Ostbank für Handel und Gewerbe w Gorzowie Wielkopolskim, następnie przeniósł się do Berlina) ${ }^{25}$. Hans Vogel uczęszczał do seminarium nauczycielskiego we Wschowej (Fraustadt),

${ }^{24}$ Gr1938, biogram Karla Jackstiena, s. 261; Gr1933, biogram Hansa Ramshorna, s. 281; Gr1943, biogram Georga Ahlemanna, s. 144; Gr1943, biogram Ericha von dem Bach-Żelewskiego, s. 149; Gr1943, biogram Hansa von Freyberga, s. 210; Gr1943, biogram Ewalda Schulza, s. 384; Gr1943, biogram Hansa Vogela, s. 416; Gr1943, biogram Hermanna Schneidera, s. 375; Gr1932, biogram Fritza Kohlsa, s. 132; Hausser: A. Schulz, G.Wegmann, D. Zienke, op. cit., s. 81; Karehne: ibidem, s. 467.

25 Gr1933, biogram Antona Hauka, s. 195; Gr1943, biogram Hermanna Schneidera, s. 375; Gr1943, biogram Ernsta Speidela, s. 394; Gr1936, biogram Arthura Kauffmanna, s. 201; Gr1936, biogram Hansa Finka, s. 136. 
a w latach 1906-1914 był nauczycielem szkół ludowych w tzw. Provinz Posen ${ }^{26}$. $\mathrm{Na}$ terenie byłego zaboru austriackiego działali późniejszy SA-Brigadeführer i emerytowany generał piechoty Alfred Krauss (kariera wojskowa w K.u.K. Armee, w 1897 roku został Generalstabschef 2. Infanterie-Division w Jarosławiu w Galicji, a następnie 33. Infanterie-Division w Komorn; w maju 1918 roku był dowódcą K.u.K. Ostarmee na Ukrainie); nazistowski poseł do Reichstagu dr Alfred Pfaff (dyrektor w przemyśle naftowym w Galicji przed 1918) ${ }^{27}$.

Na Śląsku pobierali edukację: Helmuth Brückner (szkoła ludowa w Piławie, wyższa szkoła ludowa w Bielawie, Królewskie Gimnazjum Realne w Dzierżoniowie, następnie studia - historia, filozofia, geografia na uniwersytecie we Wrocławiu); nazistowski (partyjny) specjalista od sprawdzania „czystości” krwi i pochodzenia funkcjonariuszy NSDAP (m.in. zajmował się sprawą Reinharda Heydricha w latach 30.) Dr Achim Gercke (gimnazjum humanistyczne we Wrocławiu, później studia przyrodoznawstwa we Wrocławiu, w 1930 doktorat); Erich Hasse (szkoła ludowa, gimnazjum humanistyczne w Oleśnicy); Hans Hayn (wyższa szkoła realna i gimnazjum w Legnicy); Gustav Adolf Kulisch (szkoła średnia, następnie gimnazjum w Brzegu); Georg Neugebauer (do 1915 roku katolicka szkoła ludowa w Kłodzku); Carl Friedrich hrabia von Pückler-Burghauss (gimnazjum w Nysie, studiował prawo i nauki polityczne w Bonn i we Wrocławiu); Peter Vogt (gimnazjum w Brzegu, szkoła krajowa w Wołowie); Wolfgang hrabia Yorck von Wartenburg (gimnazjum w Legnicy); Herbert Barthel (szkoła ludowa i szkoła realna we Wrocławiu); Max Fillusch (gimnazjum w Jeleniej Górze do 1914 roku); Otto Jaeschke (seminarium nauczycielskie w Bolesławcu); Alfred Jonas (szkoła ludowa i gimnazjum we Wrocławiu); Willy Marschler (szkoła ludowa w Legnicy); dr med. Karl Peschke (szkoły ludowe w Raciborzu, Opolu, Wrocławiu, gimnazjum we Wrocławiu i Katowicach, studia na uniwersytecie we Wrocławiu); Paul Roden (Volksschule w Chrzelicach (?), następnie seminarium nauczycielskie w Białej Prudnickiej); SS-Obersturmbannführer dr Walter Ruppin (studiował matematykę i nauki przyrodnicze w Getyndze oraz medycynę we Wrocławiu i Monachium); Paul Schmidt (szkoła ludowa w Kamieniu w powiecie Niemcza); Paul Skoda (szkoła ludowa w Kudowie-Zdroju); Kreisleiter NSDAP Bentheim dr med. Josef Ständer (studiował medycynę w Kilonii, Halle, Wrocławiu i Getyndze); Dr Fritz Kleiner (Mittelschule i wyższa szkoła realna w Katowicach, studia prawnicze i nauk politycznych m.in. we Wrocławiu); Alfred Krauss (uczęszczał do niższego gimnazjum w Cieszynie na Śląsku); Erich Russek (ewangelicka szkoła ludowa w Zabrzu, szkoła kupiecka w Zabrzu); Johannes Slawik (w latach 1908-1910 szkoła rolnicza w Opolu); Paul Binus (szkoła Simultanen-Knabeschule w Raciborzu); Alfred Karrasch (szkoła ludowa w Opolu,

26 Gr1943, biogram Hansa Finka, s. 416.

27 Gr1938, biogram Alfreda Kraussa, s. 288; Gr1943, biogram Alfreda Pfaffa, s. 327. 
gimnazjum humanistyczne w Opolu i Kłodzku) ${ }^{28}$. Urodzony w Pszczynie generał i SS-Oberführer Karl Hoefer, kluczowa postać w walkach niemiecko-polskich o Górny Śląsk (1919-1921, zwłaszcza w III Powstaniu Śląskim) uczęszczał do szkoły prywatnej w Katowicach, a następnie do gimnazjum w Pszczynie ${ }^{29}$. Swoją młodość w Pszczynie (lata 1886-1898) spędził wspomniany już dr Lammers, gdzie uczęszczał do tamtejszej Fürstenschule, a następnie studiował we Wrocławiu Rechts- und Staatswissenschaft. Po zrobieniu doktoratu, krótkiej karierze akademickiej i zdaniu egzaminów państwowych Lammers trafił w 1912 roku do Bytomia jako sędzia krajowy (Landrichter) ${ }^{30}$. Na Śląsku pełnili również służbę wojskową lub kształcili się w szkołach wojskowych: Paul Hoenscher (w latach 1908-1910 aktywna służba w Infanterie-Regiment Keith 1. Oberschlesisches Nr 22 w Gliwicach, Bytomiu, I wojna światowa spędzona w Reserve-Infanterie-Regiment Nr 51 we Wrocławiu); Johannes baron von Reibnitz (w latach 1901-1910 aktywny oficer w Husaren-Regiment Graf Goetzen 2. Schlesisches Nr 6 w Głubczycach); Gauamtsleiter w Gau Ost-Hannover NSDAP i oficer SA Curt Wiebel (służba m.in. w Kriegsschule w Głogowie, w 1914 awansowany na podporucznika, później udział w I wojnie); Ernst Jenke (4 lata szkoły podoficerskiej w Wołowie); Felix Piékarski (szkoła wojskowa m.in. w Wołowie); Lothar Rethel (w 1913 pobyt w szkole wojennej w Głogowie); Karl Zech (kapitan rezerwy w 3. Oberschlesisches Infanterie-Regiment Nr 62 w Koźlu, Raciborzu); Alfred Karrasch (służba w 1. Westpreußisches Pionierbataillon Nr. 17 w Toruniu); słynny dowódca Waffen-SS SS-Obergruppenführer i generał Waffen-SS Georg Keppler (szkoła wojenna w Głogowie); SS-Brigadeführer i generał-major policji Eberhard Herf (służba w Grenadier-Regiment König Wilhelm 2. Westpreußisches

28 Gr1933, biogram Helmutha Brücknera, s. 145; Gr1933, biogram Achima Gerce, s. 178; Gr1932, biogram Ericha Hasse, s. 91; Gr1933, biogram Hansa Hayna, s. 196; Gr1933, biogram Gustava Adolfa Kulischa, s. 241; Gr1933, biogram Georga Neugebauera, s. 213; Gr1933, biogram Carla Friedricha hrabiego von Pückler-Burghauss, s. 226; Gr1933, biogram Petera Vogta, s. 354; Gr1933, biogram Wolfganga hrabiego Yorck von Wartenburg, s. 374; Gr1943, biogram Herberta Barthela, s. 152; Gr1943, biogram Maxa Filluscha, s. 202; Gr1943, biogram Ottona Jaeschke, s. 254; Gr1943, biogram Alfreda Jonasa, s. 257; Gr1943, biogram Willy'ego Marschlera, s. 296; Gr1943, biogram dr Karla Peschke, s. 324; Gr1943, biogram Paula Rodena, s. 352; Gr1943, biogram dr Waltera Ruppina, s. 358; Gr1943, biogram Paula Schmidta, s. 372; Gr1943, biogram Paula Skody, s. 392; Gr1943, biogram dr Josefa Ständera, s. 397; Gr1936, biogram dr Fritza Kleinera, s. 206; Gr1938, biogram Alfreda Kraussa, s. 288; Gr1933, biogram Ericha Russka, s. 297; Gr1933, biogram Johannesa Slawika, s. 330; Gr1943, biogram Paula Binusa, s. 159; Karrasch: A. Schulz, G. Wegmann, D. Zienke, op. cit., s. 470.

29 W. Lesiuk, Hoefer Karl Julius Robert, [w:] Encyklopedia Powstań Śląskich, Opole 1982, s. 172 .

${ }^{30}$ D. Rebentisch, op. cit., s. 449; P. Lubczyk, Besuch des Reichsministers Dr. Lammers in Pleß, „Heimatkalender Pless” 1942, s. 51. W lutym 1941 Lammers odwiedził Pszczynę, gdzie był witany z wielką pompą przez tamtejsze czynniki partyjne. Miał wspominać swoją młodość w Pszczynie, por. Lubczyk, op. cit., s. 51-54. 
Nr 7. w Legnicy, następnie w Pionierbataillon Nr. 5 w Głogowie) $)^{31}$. Josef Joachim Adamczyk (później zmienił nazwisko na bardziej niemieckie: Adams) przed 1921 rokiem musiał mieszkać na części Górnego Śląska, która w wyniku decyzji Konferencji Ambasadorów przypadła Polsce, o czym świadczy passus w biogramie posłów do Reichstagu: „Seit 1921 im Preußischen Schuldienst, Flüchtlingslehrer"32. We Wrocławiu pracował przed 1914 rokiem jako dziennikarz późniejszy Gauleiter NSDAP w Brandenburgii i Komisarz Rzeszy na Białorusi Wilhelm Kube ${ }^{33}$.

Na Pomorzu kształcili się tacy naziści jak Martin Albrecht (uczęszczał do Mittelschule w Gdańsku); Willy Fruggel (szkoła miejska w Lęborku); Erhard von Schmidt (gimnazjum realne w Gdańsku); Friedrich Boschmann (szkoła średnia w Gdańsku); SA-Obergruppenführer i nadprezydent prowincji Saksonia Curt von Ulrich (gimnazjum w Gdańsku); Fritz Kohls (szkoła ludowa w Szczecinku); Erich Schmiedecke (szkoła ludowa i gimnazjum w Szczecinku); SA-Gruppenführer w Bremie Wilhelm baron von Schorlemer (gimnazjum w Kwidzyniu i Stargardzie); Heinrich Georg hrabia Fink von Finkenstein (do 1914 chodził do gimnazjum humanistycznego w Gryficach); Otto Gohdes (Bürgerschule w Złocieńcu); Hans Grüneberg (gimnazjum realne w Świnoujściu); Lutz Wysocki (w latach 1905-1917 uczęszczał do szkoły ludowej oraz szkoły przygotowawczej w Kwidzyniu); Carl Ludwig Schleich (domowa edukacja w Piątkowie, następnie uczęszczał do szkół średnich w Grudziądzu, Poznaniu i Berlinie); Otto Schmidtke (gimnazjum realne w Prabutach i w Gdańsku); od 1927 zastępca Gauleitera Pomorza, w latach 1936-1940 starosta (Landeshauptmann) Prowincji Pomorze SS-Brigadeführer Robert Schulz (w latach 1906-1914 szkoła ludowa w Pyrzycach); oficer SA z Pomorza i poseł do Reichstagu Max von Heydebreck (wyuczył się zawodu garncarza w Miastku na Pomorzu, od 1907 samodzielny mistrz rzemieślniczy); Paul Hausser (gimnazjum realne w Szczecinie); Gerhard Karehnke (w latach 1902-1913 uczęszczał do królewskiego gimnazjum humanistycznego w Gdańsku); pełnomocnik Führera do spraw gospodarczych oraz sekretarz stanu w Auswärtiges Amt, SS-Obergruppenführer Wilhelm Keppler (w latach 1905-1910 studiował budowę maszyn na politechnice w Gdańsku) ${ }^{34}$. Sprawy

31 Gr1936, biogram Paula Hoenschera, s. 186; Gr1938, biogram Johannesa barona von Reibnitz, s. 353; Gr1938, biogram Curta Wiebela, s. 452; Gr1943, biogram Ernsta Jenke, s. 256; Gr1943, biogram Felixa Piékarskiego, s. 328; Gr1943, biogram Lothara Rethela, s. 348; Gr1943, biogram Karla Zecha, s. 437; Karrasch: A. Schulz, G. Wegmann, D. Zienke, op. cit., s. 470; Keppler: ibidem, s. 501; Herf: ibidem, s. 155.

32 Gr1933, biogram Josefa Joachima Adamczyka, s. 124.

${ }^{33}$ H. Heiber, Aus den Akten des Gauleiters Kube, „Vierteljahreshefte für Zeitgeschichte” 1956, z. 1, s. 67.

34 Gr133, biogram Martina Albrechta, s. 125; Gr1933, biogram Willy’ego Fruggela, s. 176; Gr1936, biogram Erharda von Schmidta, s. 293; Gr1943, biogram Friedricha Boschmanna, s. 168; Gr1943, biogram Curta von Ulricha, s. 412; Gr1932, biogram Fritza Kohlsa, s. 132; Gr1933, biogram Ericha Schmiedecke, s. 251; Gr1933, biogram Wilhelma barona von Schorlemera, s. 314; 
służby wojskowej, kariery wojskowej rzuciły na Pomorze przyszłych nazistów, jak Friedrich Boschmann (jako szesnastolatek w 1919 roku zameldował się do Grenadier-Regiment König Friedrich I. 4. Ostpreußisches Nr 5 w Gdańsku); SA-Stumbrannführer oraz czołowy nazista księstwa Lippe, od 1934 Gauamtsleiter Gau Westfalen-Nord Walter Steinecke (w 1908 jako Fahnenjunker wstąpił do 1. Westpr. Pionier-Bataillon Nr 17, walczył w I wojnie w Prusach Wschodnich, w Polsce); Hans Peter von Heydebreck (uczęszczał do szkoły kadetów — Kadettenanstalt w Koszalinie); Paul Hausser (pobyt w Kadettenvoranstalt w Koszalinie); SS-Brigadeführer i general-major policji Erik von Heimburg (pobyt w Kadettenanstalt w Koszalinie); SS-Gruppenführer i generał-porucznik Waffen-SS Leo von Jena (w latach 1896-1897 w szkole wojennej w Gdańsku) ${ }^{35}$.

W Prusach Wschodnich kształciły się takie osoby jak dr jur. Georg Währer (studiował prawo i ekonomię w Heidelbergu, Królewcu i Kilonii); Georg Schroeder (gimnazjum w Królewcu); Ernst Nötzelmann (szkoła gminna w Grudziądzu i szkoła prywatna w Królewcu); Eugen Plorin (gimnazjum w Królewcu); Emil Stürtz (uczęszczał do Oberrealschule Bessel w Królewcu); Gauleiter Gau Düsseldorf NSDAP Karl Friedrich Florian (szkoła realna w Wehlau, dziś Znamiensk oraz w Stallupönen, dziś Niestierow); Walther Funk (gimnazjum w Insterburgu, później studia i praca w Berlinie); posiadacz gospodarstwa chłopskiego w Prusach Wschodnich, Landesbauernführer Ostpreußen Egbert Otto (uczęszczał do gimnazjum humanistycznego w Olsztynie); Ernst Rademacher (Vorschule i gimnazjum w Tylży); Alfred Preuss (szkoła ludowa w Czerwonce, Mittelschule i szkoła realna w Olsztynie); Joachim Paltzo (szkoła ludowa, gimnazjum i liceum w Kętrzynie; studia w Królewcu); dr Ernst Neumann (gimnazjum w Elblągu); Erich Fuchs (Mittelschule w Insterburgu); Waldemar Weißel (szkoła ludowa w Wysokiej Braniewskiej, szkoła średnia w Insterburgu); Ernst Penner (Mittelschule w Tylży); dr phil. Georg Usadel (szkoły ludowe w Trakehnen i Danzkehmen, gimnazjum realne w Stallupönen $)^{36}$. Z wojskiem w Prusach Wschodnich byli związani Ulrich Uhle (w 1915 wstąpił na ochotnika do Dragoner-Regiment König Albert von Sachsen

Gr1943, biogram Heinricha Georga hrabiego Fink von Finkensteina, s. 203; Gr1943, biogram Otto Gohdesa, s. 219; Gr1943, biogram Hansa Grüneberga, s. 225; Gr1943, biogram Lutza Wysockiego, s. 436; Gr1943, biogram Carla Ludwiga Schleicha, s. 367; Gr1943, biogram Ottona Schmidtke, s. 372; Gr1943, biogram Roberta Schulza, s. 383; Gr1933, biogram Maxa von Heydebrecka, s. 205; Hausser: A. Schulz, G. Wegmann, D. Zienke, op. cit., s. 80; Karehnke: ibidem, s. 467; Gr1943, biogram Wilhelma Kepplera, s. 265;

35 Gr1943, biogram Friedricha Boschmanna, s. 168; Gr1943, biogram Waltera Steinecke, s. 399; Gr1933, biogram Hansa Petera von Heydebrecka, s. 205; Hausser: A. Schulz, G. Wegmann, D. Zienke, op. cit., s. 80; von Heimburg: ibidem, s. 112; von Jena: ibidem, s. 365.

36 Gr1936, biogram dr Georga Währera, s. 340; Gr1933, biogram Georga Schroedera, s. 317; Gr1943, biogram Erwina Nötzelmanna, s. 315; Gr1933, biogram Eugena Plorina, s. 330; Gr1943, biogram Emila Stürtza, s. 404; Gr1943, biogram Karla Friedricha Floriana, s. 205; Gr1932, biogram Walthera Funka, s. 268; Gr1933, biogram Egberta Otto, s. 270; Gr1943, biogram Ernsta Rademachera, s. 343; Gr1943, biogram Alfreda Preussa, s. 334; Gr1943, biogram Joachima Paltzo, s. 321; Gr1943, biogram dr Ernsta Neumanna, s. 314; Gr1943, biogram Ericha Fuchsa, s. 213; Gr1933, 
Ostpreußisches Nr 10 w Olsztynie, udział w I wojnie); Alfred Preuss (1909-1910 jednoroczny ochotnik w Infanterie-Regiment von Boyen 5. Ostpreußisches $\mathrm{Nr} 41$ w Tylży, Kłajpedzie); Günther Arndt (udział w I wojnie z 2. Litthauisches Feldartillerie-Regiment Nr 37 w Insterburgu); Willi Bloedorn (udział w I wojnie z Infanterie-Regiment Graf Dönhoff 7. Ostpreußisches Nr 44 w Giżycku-Gołdapi); Landesbauernführer Gau Kurmark Reinhard Bredow (służba w 1. Ostpreußisches Feldartillerie-Regiment Nr 16 w Królewcu w latach 1892-1894); generał piechoty, w 1938 mianowany Reichsführerem NS-Deutscher Reichskriegerbund (Kyffhäuserbund), SS-Obergruppenführer Wilhelm Reinhard (w Korpusie Kadetów w Chełmnie, w 1904 był szefem kompanii w Füsilier-Regiment Graf Roon Ostpr. Nr 33 w Gumbinnen) ${ }^{37}$. W Prusach Wschodnich pracowali także urodzony w 1869 roku w Wiedniu, poseł do Reichstagu w 1924 z ramienia Nationalsozialistische Freiheitspartei, późniejszy Gauleiter NSDAP na Pomorzu prof. dr Theodor Vahlen (w 1897 pracował jako nieetatowy docent [Privatdozent] w Królewcu); SA-Brigadeführer w Prusach Wschodnich Fritz Adam (praca w stoczni w Elblągu, z wykształcenia Bauingenieur) ${ }^{38}$.

\section{Życie w latach 1918-1939}

Paru przyszłych nazistów żyło i funkcjonowało w odrodzonej w 1918 roku Polsce. Ciekawym przykładem może być Ludwig Wolff, urodzony 4 sierpnia 1908 w Pabianicach, w niemieckiej rodzinie. Jego ojcem był Ludwig Wolff senior (1859-1923), który w 1919 został posłem na Sejm RP (zrzekł się mandatu), i który był działaczem DtB (Deutschtumsbund zur Wahrung der Minderheitsrechte in Polen). Wolff junior był obywatelem Polski, chodził do gimnazjum niemieckiego w Łodzi, następnie studiował na Uniwersytecie Warszawskim oraz w Erlangen. Służył w Wojsku Polskim. Był aktywnym działaczem mniejszości niemieckiej w Polsce: głównie przywódcą niemieckiej młodzieży (ab 1. Oktober 1934 hauptamtlicher Jugendführer im Auftrage der Reichsjugendführung und des VdA im ehemals mittelpolnischen Gebiet). Od lutego 1936 był zastępcą przewodniczącego Deutscher Volksverband w Polsce, a od 15 maja 1938 przywódcą (Verbandsführer) tej organizacji. 28 sierpnia 1939 miał zostać aresztowany przez polskie władze i oskarżony o zdradę państwa polskiego i osadzony najpierw w Warszawie, a później w Brześciu nad Bugiem, wkrótce uwolniony przez Wehrmacht. Po zajęciu Polski przez Niemców jego kariera nabrała rozpędu:

biogram Waldemara Weißela, s. 365; Gr1938, biogram Ernsta Pennera, s. 337; Gr1938, biogram dr Georga Usadela, s. 433.

37 Gr1943, biogram Ulricha Uhle, s. 411; Gr1943, biogram Alfreda Preussa, s. 334; Gr1943, biogram Günthera Arndta, s. 147; Gr1943, biogram Williego Bloedorna, s. 161; Gr1943, biogram Reinharda Bredowa, s. 170; Gr1943, biogram Wilhelma Reinharda, s. 343.

38 Gr1924, biogram Theodora Vahlena, s. 546; Gr1936, biogram Fritza Adama, s. 95. 
jesienią 1939 został szefem Hitlerjugend w Łodzi jako HJ-Oberbannführer; otrzymał Goldenes Ehrenzeichen der NSDAP (odznaczony osobiście przez Hitlera) oraz został Kreisleiterem NSDAP w Łodzi (30 stycznia 1940 roku); wstąpił do SS i został awansowany do stopnia SS-Standartenführera w Stabshauptamt Reichskommissar für die Festigung des deutschen Volkstums ${ }^{39}$. Po pewnym czasie kariera Wolffa załamała się: wedle M. Cygańskiego „mimo swej gorliwości i zasług dla III Rzeszy L. Wolff został usunięty we wrześniu 1941 r. — z nieznanych bliżej przyczyn - ze stanowiska Kreisleitera NSDAP w Łodzi" ${ }^{40}$. Z kolei Kreisleiterem NSDAP na powiat łódzki był dawny działacz JdP w Polsce centralnej Herbert Mees, który od 1941 pełnił funkcję starosty powiatu łódzkiego ${ }^{41}$.

Wypada wspomnieć również o Rudolfie Wiesnerze (1890-1973), który był prezesem JDP (Jungdeutsche Partei), zaś w latach 1935 i 1938 senatorem RP. W 1933 roku został on prezesem JDP (Landesleiter). JDP była niemiecką partią działającą w Polsce, które miała wybitnie pronazistowskie oblicze. D. Matelski pisał, że: ,przyjęcie nazwy Partia Młodoniemiecka oznaczało odcięcie się od działaczy, kierujących dotychczas życiem mniejszości niemieckiej w Polsce, związanych z ziemiaństwem i korpusem oficerskim byłej armii niemieckiej, a nazywanych »obozem starych «". Niektórzy działacze krytykowali Wiesnera za wodzowski styl rządzenia partią oraz ugodową politykę wobec polskich władz ${ }^{42}$. W 1935 roku w związku z wyborami do Sejmu i Senatu (8/15 września 1935) prezydent I. Mościcki zgodnie z porozumieniem zawartym między DVW i JDP a BBWR mianował senatorem Rudolfa Wiesnera. W roku 1938 Wiesner nie został już mianowany senatorem z powodu jego nazistowskiej, „wywrotowej” polityki partyjnej. W tymże roku okazał swoje nazistowskie poglądy i wykonywał działania co najmniej kontrowersyjne wobec państwa polskiego (wysłanie telegramu z gratulacjami do kanclerza Hitlera po zajęciu Austrii w marcu 1938; przedstawienie w kwietniu 1938 memorandum dla władz RP z żądaniem wielu przywilejów dla mniejszości niemieckiej w Polsce, które zostało odrzucone przez polskie MSW). Wiesner był tak ambitny, że — na wzór Konrada Henleina w Czechosłowacji - pragnął zostać przywódcą ruchu niemieckiego w Polsce, a w okresie kryzysu sudeckiego oraz zaraz po nim (jesień 1938) wraz z Kohnertem zaczął wysuwać żądania uzyskania autonomii narodowościowej w Polsce ${ }^{43}$. Po 1939 roku Wiesner został posłem do Reichstagu (MdR), członkiem NSDAP i SS (mianowany SS-Oberführerem) i dalej rezydował w Bielsku-Białej ${ }^{44}$. Hans

39 Gr1943, biogram Ludwiga Wolffa, s. 433; D. Matelski, Niemcy w Polsce w XX wieku, Warszawa-Poznań 1999, s. 90; M. Cygański, op. cit., s. 40.

40 M. Cygański, op. cit., s. 140.

41 Ibidem, s. 140.

42 D. Matelski, op. cit., s. 93-94.

43 Ibidem, s. 97-98, 172-173.

44 Wiesner z powodu przedwojennych zatargów z potężnym szefem SS-VOMI SS-Ogruf. Wernerem Lorenzem po 1939 popadł w niełaskę, a jego największym sukcesem był „wybór” na posła do Reichstagu, por G. Jérome, Les milices d'autoprotection de la communauté allemande de Po- 
Hans Joachim Kohnert(1905-1972) był obywatelem RP, działaczem Deutsche Vereinigung im Sejm und Senat für Posen, Netzegau und Pomerellen (Deutsche Vereinigung, DV), a w latach 1935-1939 prezesem DVW (Deutsche Vereinigung in Westpolen). Biorąc przykład z Niemców sudeckich i ich przywódcy, Henlein Kohnert z DVW oraz Wiesner z JDP wysunęli w imieniu swoich organizacji żądania uzyskania autonomii narodowościowej w Polsce. Dr Kohnert uczestniczył w rozmowach (1938-1939) polskich Niemców o powołaniu jednej organizacji naczelnej Niemców w Polsce pod nazwą Bund Deutscher in Polen ${ }^{45}$. Po 1939 roku dr Kohnert został Landesbauernführerem w Kraju Warty oraz przyjęty do NSDAP i SS, gdzie otrzymał stopień SS-Oberführera ${ }^{46}$. Podobnie wspomniany już Ulrich Uhle (ur. 21 maja 1897 roku w Gorzewie w Wielkopolsce) po 1918 roku został obywatelem Polski, przejął Gorzewo od ojca. Został działaczem Jungdeutsche Partei für Polen, jej mówcą, pisarzem, JdP-Ortsgruppenleiterem. W 1935 został naczelnikiem okręgu (Gauleiterem) JdP w okręgu poznańskim, pełnił tę funkcję

mérélie, Posnanie et Silésie Polonaise, „Guerres mondiales et conflits contemporains” 1991, nr 163, s. 71. Jesienią 1939 roku Wiesner miał zostać mianowany zastępcą Gauleitera Śląska Wagnera, ale ostatecznie do tego nie doszło. Wiesner był bardzo rozgoryczony — krytykował czołowych nazistów na Śląsku za ich politykę narodowościową. Ryszard Kaczmarek napisał, że „oficjalne negowanie polityki gauleitera, prowadzonej w porozumieniu z Himmlerem, musiało w konsekwencji spowodować odsunięcie Wiesnera i pozbawienie go jakiegokolwiek wpływu na działalność administracji cywilnej. Pozostała mu tylko do odegrania rola człowieka wygłaszającego w całych Niemczech wykłady na temat polityki wschodniej”, zob. R. Kaczmarek, Górnośląscy Niemcy w administracji niemieckiej rejencji katowickiej, [w:] Górny Śląsk i Górnoślązacy w II wojnie światowej, red. W. Wrzesiński, Bytom 1997, s. 61-62. Ze spisu czołowych oficerów SS (tzw. dębowców) Dienstaltersliste der Schutzstaffel der NSDAP. Stand vom 9 November 1944 (Berlin 1944, s. 27) można dowiedzieć się, że Rudolf Wiesner, ur. 11 grudnia 1890, był posłem do Reichstagu, posiadał m.in. odznaczenia jak Goldenes Ehrenzeichen der NSDAP i Krzyż Żelazny II klasy, pierścień SS, został mianowany SS-Oberführerem 1 maja 1940, jesienią 1944 roku przypisanym do Głównego Urzędu Bezpieczeństwa Rzeszy, porucznikiem rezerwy. Wiesner dopiero po 1939 roku wstąpił do NSDAP i SS, o czym świadczą jego wysokie numery legitymacji NSDAP (nr 7777 970) i SS (nr 365 138). Karol Grünberg pisał, że Wiesner był poszukiwany przez władze Polski Ludowej za popełnione w latach 1939-1940 przestępstwa na terenie Bielska-Białej oraz że ,ukrywając się po wojnie w RFN pod nazwiskiem Wendtorf, Wiesner popełnił szereg malwersacji finansowych i pod tym zarzutem został osadzony w więzieniu", por. K. Grünberg, SS-czarna gwardia Hitlera, Warszawa 1985, s. 545.

45 D. Matelski, op. cit., s. 173-174.

46 Dr Hans Kohnert (ur. 28 czerwca 1905), członek NSDAP (nr leg 7848 301), członek SS (nr 356 871), został mianowany SS-Oberführerem 13 listopada 1939 roku, odznaczony Goldenes Ehrenzeichen der NSDAP, por. Dienstaltersliste der Schutzstaffel der NSDAP. Stand vom 9 November 1944 (Berlin 1944), s. 26. Zdaniem M. Cygańskiego dr Kohnert, Ludwig Wolff czy Georg Joschke w okresie przed 1939 byli „mężami zaufania” urzędu SS-VOMI i jego szefa SS-Obergruppenführera Wernera Lorenza, por. M. Cygański, SS w polityce zagranicznej III Rzeszy w latach 1934-1945, Warszawa-Wrocław 1975, s. 126. Po nominacji Kohnerta na Landesbauernführera w Kraju Warty pisano: „Dr Kohnert, als Kind dieses Landes, als Sohn eines Bauern stehe es zu, an gewichtiger Stelle am Aufbau des Warthelandes, seiner Heimat zu wirken. Dr Kohnert kenne die Sorgen des Landvolkes; er verkörpert alteingesessenes Bauerntum gepaart mit politischem Führertum. Es sei allen ein Herzensbedürfnis, dem deutschen Landvolk im Wartheland einen Sohn dieses Landes zum Führer geben zu können.”, por. „Wartheländischer Bauernkalender 1942”, Posen 1942, s. 42. 
do wybuchu wojny. Po wkroczeniu Niemców do Polski, Uhle gorliwie współdziałał ze swoimi rodakami w tworzeniu niemieckiego Selbstschutzu (organizacji bynajmniej nie pokojowej) oraz w przejmowaniu przez Niemców administracji i majątku państwa polskiego (Nach dem Einmarsch der deutschen Wehrmacht Mitarbeiter am Ausbau des Selbstschutzes und an der Überleitung der Verwaltung in deutsche Hand). W listopadzie 1939 został drugim Gauinspekteurem Gau NSDAP Wartheland, SS-Oberführerem, Gauhauptamtsleiterem; dalej rezydował w Gorzewie ${ }^{47}$. Georg Joschke (urodzony 6 kwietnia 1900 roku we Wrocławiu) był także polskim obywatelem: w latach 1932-1939 członek Jungdeutsche Partei für Polen, kierownik (Kreisleiter) tej partii w Katowicach, następnie na Śląsku, a później zastępca szefa Jungdeutsche Partei für Polen w Polsce. Jesienią 1939 był członkiem Freikorps Ebbinghausen. Po zakończeniu działań wojennych został Kreisleiterem NSDAP w Katowicach ${ }^{48}$. Można przedstawić także losy Ewalda Schulza urodzonego 31 maja 1896 w Dziechowie (Sechau, powiat Sępólno Krajeńskie), który od 1920 był obywatelem polskim oraz aktywnym politycznie członkiem mniejszości niemieckiej w Polsce. Od 1939 aktywna służba w Reichsgau Danzig-Westpreußen: Kreiswirtschaftsberater w Kamieniu Krajeńskim (niem. Kamin), posiadacz młyna (był mistrzem młynarskim), oficer NSFK, Kreisrat, poseł do Reichstagu ${ }^{49}$.

$\mathrm{Na}$ Śląsku żyli, działali, kształcili się w okresie międzywojennym: Konrad Ritsch (szkoły ludowe w Nowej Soli i w Lubinie, matura w 1925 roku, później studiował m.in. we Wrocławiu); dr jur. Ernst Krappe (w 1920 uzyskał stopień doktora nauk prawnych we Wrocławiu); Kreisleiter NSDAP na Śląsku Rudolf Klieber (szkoła rolnicza w Świdnicy); Richard Türk (seminarium rolnicze w Świdnicy); Max Fillusch (studia na uniwersytecie wrocławskim w latach 1918-1920, po 1921 radny w Zabrzu); Bruno Müller-Reinert (studia we Wrocławiu); funkcjonariusz berlińskiej NSDAP, w latach 1932-1940 kierownik Rechtsamt Gau Berlin NSDA dr Reinhard Neubert (w 1922 został doktorem prawa na uniwersytecie we Wrocławiu $)^{50}$. Prowadzili działalność gospodarczą, własne gospodarstwa, pracowali w administracji czy szkolnictwie: Herbert Barthel (po 1920 roku m.in. zamieszkiwał we Wrocławiu, Świdnicy, od 1933 roku w Westfalii); Erhard von

47 Gr1943, biogram Ulricha Uhle, s. 411; D. Matelski, op. cit., s. 94. Ulrich Uhle występuje jako właściciel mleczarni dworskiej w Gorzewie w spisach mleczarstwa wielkopolskiego, por. Statystyka mleczarstwa w Wielkopolsce i spis mleczarń za lata 1931 i 1932, Poznań 1934, s. 48. Uhle był członkiem NSDAP (nr leg 7675 748) i SS (nr 393 261), został mianowany SS-Oberführerem 13 grudnia 1939 roku, por. Dienstaltersliste der Schutzstaffel der NSDAP. Stand vom 9 November 1944 (Berlin 1944), s. 26).

48 Gr1943, biogram Georga Joschke, s. 259.

49 Gr1943, biogram Ewalda Schulza, s. 384.

50 Gr1933, biogram Konrada Ritscha, s. 290; Gr1932, biogram dr Ernsta Krappe, s. 133; Gr1943, biogram Rudolfa Kliebera, s. 268; Gr1943, biogram Richarda Türka, s. 410; Gr1943, biogram Maxa Filluscha, s. 202; Gr1943, biogram Brunona Müller-Reinerta, s. 308; Gr1943, biogram Reinharda Neuberta, s. 313. 
Schmidt (prowadził gospodarstwo chłopskie w Sadowicach w powiecie wrocławskim, później jako kupiec w Rzeszy); Gaugeschäftsführer i zastępca Gauleitera Gau München-Oberbayern oraz kierownik Reichspropagandaamt München-Oberbayern Otto Nippold (po 1918 przez kwartał jako praktykant leśny terminował przy Landwirtschaftskammer Breslau we Wrocławiu); Gustav Adolf Kulisch (praca w banku w Świdnicy, a następnie w firmie w Świdnicy); Karl Brückner (w latach 1918-1921 kupiec w Nysie); Otto Jaeschke (od 1920 posiadał gospodarstwo chłopskie w Górzynie w powiecie wołowskim); Hermann Schneider (od 1922 dzierżawca dóbr rycerskich w Biestrzykowicach w powiecie Namysłów); dr med. Karl Peschke (do 1933 pracował jako lekarz w Środzie Śląskiej); Erwin Schramm (praca w administracji miasta Biała Prudnicka); Carl Friedrich hrabia von Pückler-Burghauss (rolnik we własnym gospodarstwie Friedland, dziś Korfantów na Opolszczyźnie); Erich Russek (działał w Polsce, w Katowicach i na polskim Górnym Śląsku — prowadził firmę, która zakończyła swą działalność w 1926 roku; później w niemieckiej części Górnego Śląska); funkcjonariusz Gau NSDAP Schlesien Niederschlesien, od 1934 nadburmistrz Zgorzelca Konrad Jenzen (zastępca okręgowego przywódcy Gauwart Deutschvölkischer Schutz- und Trutzbund na Śląsku; w latach 1927-1933 działacz NSDAP, m.in. radny w Zgorzelcu); Wyższy Dowódca SS i Policji oraz dowódca nadodcinka SS w Kraju Warty Theodor Berkelmann (w latach 1926-1930 działalność militarno-sportowa na Górnym Śląsku); Alfred Karrasch (w latach 1919-1926 pracował w Schutzpolizei w Katowicach, Gliwicach i Opolu), Hans Jüttner (służba w wojsku, następnie w SA-Gruppe Schlesien we Wrocławiu w latach 30. $)^{51}$.

Na Pomorzu w latach 1918-1939 pracowali w administracji, w szkolnictwie, prowadzili własną działalność gospodarczą tacy funkcjonariusze nazistowscy jak: Arthur Greiser, który koniec wojny spędził w szpitalu wojskowym w Gdańsku; po 1918 przebywał i działał w Wolnym Mieście Gdańsku. W 1921 roku związał się z tamtejszą masonerią, w 1922 zapisał się do Niemieckiej Partii Społecznej (Deutschsoziale Partei) w Gdańsku oraz związał się szowinistyczną organizacją Kamerad, a w 1924 założył Stahlhelm w tym mieście, później działał jako przedstawiciel handlowy. $\mathrm{Z}$ powodu utrustowienia branży oraz rzekomego bojkotu firm żydowskich musiał zakończyć tę działalność gospodarczą. Następnie zajmował się holowaniem i przewozem pasażerów motorówką po Zatoce Gdańskiej.

51 Gr1943, biogram Herberta Barthela, s. 152; Gr1936, biogram Erharda von Schmidta, s. 293; Gr1938, biogram Ottona Nippolda, s. 329; Gr1933, biogram Gustava Adolfa Kulischa, s. 241; Gr1943, biogram Karla Brücknera, s. 172; Gr1943, biogram Ottona Jaeschke, s. 254; Gr1943, biogram Hermanna Schneidera, s. 375; Gr1943, biogram Karla Peschke, s. 324; Gr1943, biogram Erwina Schramma, s. 377; Gr1933, biogram Carla Friedricha hrabiego von Pückler-Burghauss, s. 226; Gr1933, biogram Ericha Russka, s. 297; Gr1943, biogram Konrada Jenzena, s. 256; Gr1943, biogram Theodora Berkelmanna, s. 157. Karrasch: A. Schulz, G. Wegmann, D. Zienke, op. cit., s. 470; Jüttner: ibidem, s. 388. 
Od 1930 roku związany zawodowo z Gauleitung NSDAP w Gdańsku ${ }^{52}$. Już w „gdańskim” okresie swojego życia (do 1939) Greiser zajmował wyraźnie antypolskie stanowisko (postulowanie opuszczenia przez Polaków Gdańska, tolerowanie antypolskich posunięć gdańskich władz, jak dyskryminacja, wyrzucanie z pracy, groźby, pobicia, zamykanie polskich szkół i innych organizacji etc. $)^{53}$. Można wskazać na takie postacie, jak działacz gdańskiej NSDAP przed 1933, później Reichsamtsleiter w Reichsleitung NSDAP, SS-Standartenführer Ralf Brockhausen (między 1919 a 1939 przez 5 lat działał w Wolnym Mieście Gdańsku, zapewne jako kupiec); prawnik, adwokat i notariusz, pruski radca stanu i poseł do Reichstagu dr jur. Rüdiger hrabia von der Goltz (w latach 1926-1934 pracował jako adwokat w Szczecinie, w 1933 został przewodniczącym pomorskiego sejmu krajowego [Landtag], później praca w Berlinie); Gaugeschäftsführer i zastępca Gauleitera Gau Düsseldorf SA-Brigadeführer Carl Overhues (po odejściu z wojska był kupcem w branży samochodowej i ubezpieczeń w Gdańsku i w Nadrenii); Hans Grüneberg (po 1918 pobyt w Szczecinie: praca na kolei Rzeszy w Szczecinie, później w pomorskiej Izbie Rolniczej); Arthur Kauffmann (urzędnik [Abteilungsleiter] w kasie chorych w Słupsku); Otto Gohdes (od 1922 urzędnik leśny w Preußsische Staatsoberförsterei Neuhof w powiecie Drawsko Pomorskie); SA-Obergruppenführer, od 20 kwietnia 1941 niemiecki poseł w Chorwacji Siegfried Kasche (w latach 1920-1921 służba w Arbeitsgemeinschaft na Pomorzu); Kurt Kaul (w 1925 roku wstąpił do organizacji paramilitarnej Der Kamerad w Gdańsku); działacz wschodniopruskiej NSDAP (od 1935 Landesbauernführer Ostpreußen, Gauamtsleiter für Agrarpolitik, a później für Landvolk w Gau Ostpreußen) i SS-Brigadeführer Erich Spickschen (od 1919 działalność jako rolnik na Pomorzu i w Danii, w latach 1923-1926 dzierżawił gospodarstwa na Pomorzu i w Prusach Wschodnich); dowódca SA w Złotowie, a później w Człuchowie, SA-Brigadeführer Ernst Keller (prowadził gospodarstwo chłopskie w Przechlewie w powiecie człuchowskim od 1927); dr med. Gerhard Karehnke (praktyki, następnie praca w szpitalu miejskim oraz w miejskiej klinice położniczej w Wolnym Mieście Gdańsku, następnie lekarz Schutzpolizei Wolnego Miasta Gdańska, aktywny w tamtejszym Czerwonym Krzyżu $)^{54}$.

52 Gr1943, biogram Arthura Greisera, s. 221. Greiser w latach 1921-1927 był związany z gdańską masonerią — był członkiem loży Jana „Feste Burg im Osten” w Gdańsku, w 1923 roku osiągnął trzeci stopień wtajemniczenia, zob. C. Łuczak, op. cit., s. 9.

53 C. Łuczak, op. cit., s. 64-65. Przed polskimi władzami z kolei Greiser odgrywał rolę bądź „głupiego”, bądź „nieświadomego” antypolskich posunięć w Wolnym Mieście Gdańsku.

54 Gr1943, biogram Ralfa Brockhausena, s. 172; Gr1938, biogram Rüdigera hrabiego von der Goltz, s. 223; Gr1943, biogram Carla Overhuesa, s. 320; Gr1943, biogram Hansa Grüneberga, s. 225; Gr1936, biogram Arthura Kauffmanna, s. 201; Gr1943, biogram Ottona Gohdesa, s. 219; Gr1943, biogram Siegfrieda Kasche, s. 263; Gr1943, biogram Kurta Kaula, s. 264; Gr1943, biogram Ericha Spickschena, s. 395; Gr1936, biogram Ernsta Kellera, s. 202; Karehnke: A. Schulz, G. Wegmann, D. Zienke, op. cit., s. 467. 
Odbywali służbę wojskową jak Erich von dem Bach-Żelewski (do 1924 służba w Infanterie-Regiment Nr 4 w Stargardzie); współpracownik Goebbelsa, Kreisleiter NSDAP Kreis Groß-Berlin, Gaupropagandaleiter Gau Groß-Berlin Werner Wächter (korpus kadetów w Koszalinie), Hans Jüttner (w Kraftfahrttruppen w II Armee-Korps w Szczecinie); Fritz Kraemer (praca w policji w Szczecinie, później dowódca plutonu w Koszalinie w latach 20. $)^{55}$. Czołowy przedstawiciel SS w okupowanej Polsce SS-Obergruppenführer i generał policji Wilhelm Koppe w latach 1934-1935 był dowódcą Odcinka SS w Wolnym Mieście Gdańsku (Führer SS-Abschnitt XXVI Danzig), z kolei Werner Lorenz w 1931 wstąpił do SS w Gdańsku ${ }^{56}$. Heinrich Schoene, członek NSDAP i SA, od 1934 dowódca SA-Gruppe Ostland (obejmowała też Gdańsk), w 1934 awansowany do stopnia SA-Ogruppenführera, w latach 1934-1942 był prezydentem policji w Królewcu; Eberhard Ponndorf, który po 1936 był dowodcą NSKK-Motorgruppe Ostland, obejmującej swym zasięgiem m.in. Gdańsk i Gau Ostpreußen ${ }^{57}$. Hans Kammler kształcił się w gimnazjum miejskim w Gdańsku, a później służył ochotniczo w Leibhusaren-Regiment Königin Viktoria von Preußen Nr 2 w Gdańsku. Po zdaniu matury w rzeczonym gimnazjum studiował na wydziale architektur. Politechniki (Technische Hochschule) w Gdańsku; studia (z przerwami) ukończył w 1923 roku $^{58}$. Gauhaupamtsleiter NSDAP Baden dr Reinhold Roth w latach 1919-1923 studiował w Wyższej Szkole Technicznej (Technische Hochschule) w Hannowerze i w Gdańsku ${ }^{59}$.

W Prusach Wschodnich w latach 1918-1939 studiowali, pracowali, prowadzili interesy: dr phil Georg Usadel (studia w Królewcu, w 1923 został doktorem filozofii, następnie radca miejski w Insterburgu); Wolfgang hrabia Yorck von Wartenburg (studiował prawo w Monachium, Królewcu, Berlinie); Niemiec bałtycki urodzony w Rydze; w latach 1929-1934 działał w Rydze jako adwokat, późniejszy SS-Oberführer dr jur. Erhard Kroeger (studia - prawo i historia w Dorpacie, Rydze, Tybindze i Królewcu); Werner Kuhnt (w końcu 1920 roku prawdopodobnie wyemigrował z Polski do Rzeszy, w latach 30. studiował we Wrocławiu i Królewcu); Otto Schmidtke (studiował prawo oraz nauki polityczne tudzież języki nowożytne w Hamburgu i w Królewcu); Lothar Rethel (po 1918 studiował semestr na uniwersytecie w Królewcu); działacz wschodniopruskiej NSDAP: Gaugeschäftsführer, zastępca Gauleitera Ferdinand Grossherr (po 1919 prowadził interesy handlowe w Królewcu); Reichsleiter NSDAP, Reichsminister für Ernährung und Landwirtschaft, Reichsbauernführer, SS-Obergruppenführer Richard Walther Darré (wolontariusz przy wschodniopruskim Stutbuch-Gesellschaft w Insterburgu); Hans Adolf Prützmann (7 lat pracował jako urzędnik do

55 Gr1943, biogram Ericha von dem Bach-Żelewskiego, s. 149; Gr1943, biogram Wernera Wächtera, s. 417; Jüttner: A. Schulz, G. Wegmann, D. Zienke, op. cit., s. 388; Kraemer: ibidem, s. 588.

56 Gr1943, biogram Wilhelma Koppe, s. 273; Gr1943, biogram Wernera Lorenza, s. 292.

57 Gr1943, biogram Heinricha Schoene, s. 376 i Eberharda Ponndorfa, s. 331.

58 A. Schulz, G.Wegmann, D. Zienke, op. cit., s. 442-443.

59 Gr1943, biogram Rudolfa Rotha, s. 356. 
spraw rolnictwa na Pomorzu, w Brandenburgii, w Prusach Wschodnich); SA-Obergruppenführer i po 1939 Generalny Komisarz Rzeszy w Estonii Karl-Siegmund Litzmann (po 1919 rolnik w Saksonii i Prusach Wschodnich); Werner Lorenz (do 1934 był dowódcą SS-Oberabschnitt Nordost w Królewcu) ${ }^{60}$.

\section{Udział w I wojnie na ziemiach polskich}

Na terenach byłej Rzeczypospolitej Obojga Narodów w I wojnie światowej walczyli między innymi: jeden z czołowych austriackich nazistów, w latach 1940-1945 Komisarz Rzeszy w Holandii dr Arthur Seyss-Inquart (na froncie karpackim, udział w bitwie pod Gorlicami, został ranny); działacz austriackiej NSDAP (m.in. udział w nieudanym puczu nazistów w Wiedniu z 1934, aresztowany i skazany na więzienie) po 1938 SS-Oberführer i wiceburmistrz Wiednia Hanns Blaschke (udział w I wojnie w K.u.K. Armee na Wołyniu, m.in. tereny Łucka i na froncie karpackim); działacz SdP w Czechosłowacji, po 1938 Kreisleiter NSDAP w Saaz (Kraj Sudecki) i Gauamtsleiter Rudolf Dietl (udział w I wojnie w armii austro-węgierskiej, walki w Galicji, na froncie karpackim); Wilhelm Dressler (udział w I wojnie, służba w twierdzy Przemyśl, po jej upadku dostał się do niewoli rosyjskiej — do 1920 pobyt na Syberii); działacz Sudetendeutsche Partei (SdP), później NSDAP oraz Generalluftschutzführer Ludwig Frank (udział w I wojnie w armii austro-węgierskiej, walki w Galicji); Hermann Kretzschmann (walki w Karpatach); działacz SdP i współpracownik Henleina, RAD-Generalarbeitsführer Anton Pfrogner (w K.u.K. Armee, ranny w sierpniu 1914 w Galicji Wschodniej pod Przemyślanami; w 1915 na froncie karpackim); działacz austriackiej NSDAP Toni Plankensteiner (walki w Galicji); działacz SdP Dr Hubert Preibsch (w K.u.K. Armee, walki w Karpatach); funkcjonariusz Reichsleitung NSDAP (praca dla głównego skarbnika NSDAP Franza Xavera Schwarza) Hermann Ried (walki w Galicji); SS-Standartenführer, działacz berlińskiej NSDAP Walter Schuhmann (walki w Galicji Wschodniej); SS-Brigadeführer i generał-major policji Ernst Hartmann (walki na froncie karpackim w 1916); SS-Brigadeführer i generał-major Waffen-SS Desidarius Hampel (na kursie szkoleniowym dla niemieckich oficerów w Truskawcu); SS-Brigadeführer i generał-major Waffen-SS Peter Hansen (pobyt na 12-tygodniowym kursie dla oficerów wywiadu w Brzeżanach; następnie po zakończeniu wojny został oddelegowany jako oficer łącznikowy przy międzyalianckiej

60 Gr1938, biogram Georga Usadela, s. 433; Gr1933, biogram Wolfganga hrabiego Yorck von Wartenburg, s. 374; Gr1943, biogram Erharda Kroegera, s. 279. „Ostdeutscher Beobachter” z 22 listopada 1939 (s. 5) opisał wizytę Kroegera u Gauleitera Greisera („Der Führer der Baltendeutschen, SS-Standartenführer Dr Erhard Kroeger...”). Gr1943, biogram Wernera Kuhnta, s. 282; Gr1943, biogram Ottona Schmidtke, s. 372; Gr1943, biogram Lothara Rethela, s. 348; Gr1943, biogram Ferdinanda Grossherra, s. 224; Gr1943, biogram Richarda Walthera Darré, s. 182; Gr1943, biogram Hansa Adolfa Prützmanna, s. 335; Gr1943, biogram Karla-Siegmunda Litzmanna, s. 290; Gr1943, biogram Wernera Lorenza, s. 292. 
komisji wojskowej w Polsce i na Litwie); SS-Brigadeführer, generał-major Konrad Hornung (służba w K.u.K. Armee, w latach 1914-1915 przy Artilleriestabsabteilung w twierdzy Kraków); SS-Brigadeführer i generał-major policji Oskar Knofe (walki nad Narwią, walki w Galicji) ${ }^{61}$; piastujący wysokie stanowiska w SA (m.in. Chef des Personalhauptamtes der Obersten SA-Führung) SA-Gruppenführer Hans Petersen (udział w Winterschlacht na Mazurach 1915 roku); Gauredner i Reichsredner, działacz NSDAP w Turyngii Paul Papenbroock (w 1916 został ranny na froncie nad Narwią, w latach 1916-1917 w armii tureckiej); Gauschatzmeister Gau NSDAP Württemberg Anton Vogt (w 1916 był Unterzahlmeister przy Infanterie-Ersatz-Truppe Warschau w Warszawie); SS-Sturmbannführer oraz Gauamtsleiter für Agrarpolitik Gau Magdeburg Alexander Schrader (udział w I wojnie, po zatruciu gazem na froncie, służył jako podoficer w Jüteborgu, Giżycku i Malborku do listopada 1918); Leo von Jena (w latach 1914-1915 dowódca kompanii, a później batalionu w 5. Garde-Regiment zu Fuß na Mazurach); Bruno Czarnowski / Scharno (pod koniec wojny zgłosił się jako ochotnik do Infanterie-Regiment von Borcke 4. Pommersches Nr 21 w Toruniu); Kreisleiter NSDAP w Steinmetz Hermann Müller (Flugzeugführer w szkole obserwatorów Beobachterschule w Słupsku $)^{62}$. Likwidator getta warszawskiego, jeden z największych zbrodniarzy w samej SS, SS-Gruppenführer Jürgen Stroop od połowy 1915 roku przebywał z wojskami niemieckimi na ziemiach polskich (Polska, Litwa, Białoruś, Polesie, Galicja). W Galicji, w Brzeżanach (dziś na terenie Ukrainy) Stroop miał zakochać się w pewnej Polce, a uczucie było podobne tak silne, że planował ożenić się z nią i być może osiąść w Polsce, od czego odwiodła go jego wybitnie nacjonalistyczna rodzina (Polka „niegodna” była Niemca). Podobno korespondował z ową Polką aż do 1922 roku, a w latach II wojny światowej Stroop złożył wizytę w Brzeżanach i bezskutecznie ,poszukiwał” dawnej sympatii ${ }^{63}$. Minister Rzeszy i Chef der Reichskanzlei, SS-Obergruppenführer dr Lammers w latach I wojny (do 1917) walczył na froncie ze śląskim pułkiem piechoty, gdzie stracił lewe oko, a następnie jako kapitan rezerwy został przeniesiony do Warszawy, gdzie pełnił służbę przy „Verwaltungschef des kaiserlichen Generalgouvernements Warschau"64.

61 Gr1943, biogram Arthura Seyss-Inquarta, s. 389 oraz J. Koll, From the Habsburg Empire to the Third Reich: Arthur Seyß-Inquart and National Socialism, [w:] Austrian Lives, G. Bischof, F. Plasser, E. Maltschnig (eds.), New Orleans 2012, s.128; Gr1943, biogram Hannsa Blaschke, s. 161; Gr1943, biogram Rudolfa Dietla, s. 186; Gr1943, biogram Wilhelma Dresslera, s. 190; Gr1943, biogram Ludwigka Franka, s. 207; Gr1943, biogram Hermanna Kretzschmanna, s. 279; Gr1943, biogram Antona Pfrognera, s. 328; Gr1943, biogram Toniego Plankensteinera, s. 329; Gr1943, biogram Herberta Preibscha, s. 334; Gr1943, biogram Hermanna Rieda, s. 351; Gr1943, biogram Waltera Schuhmanna, s. 381; Hartmann: A. Schulz, G. Wegmann, D. Zienke, op. cit., s. 73; Hampel: ibidem, s. 18; Hansen: ibidem, s. 40-41; Hornung: ibidem, s. 330; Knofe: ibidem, s. 542.

62 Gr1943, biogram Hansa Petersena, s. 325; Gr1943, biogram Paula Papebroocka, s. 322; Gr1943, biogram Antona Vogta, s. 416; Gr1943, biogram Alexandra Schradera, s. 377; von Jena: Schulz, s. 365; Gr1943, biogram Bruno Scharno, s. 363, Gr1936, biogram Hermanna Müllera, s. 241.

63 K. Moczarski, Rozmowy z katem, Warszawa 2000, s. 50-53.

64 D. Rebentisch, Lammers Hans Heinrich, s. 449. 


\section{Walki polsko-niemieckie}

Ważnym „motywem” w kontaktach z polskością było uczestnictwo w walkach polsko-niemieckich w latach 1918-1921 zogniskowanych w ramach walk w Wielkopolsce (Powstanie Wielkopolskie 1918-1919), na Górnym Śląsku i na Opolszczyźnie (I Powstanie Śląskie 1919, II Powstanie Śląskie 1920, III Powstanie Śląskie 1921), na Pomorzu, na Litwie czy w ramach mniejszych potyczek i starć. Już sam akces do różnorakich Freikorpsów i innych organizacji paramilitarnych był znamienny - częstokroć nie był oznaką ,patriotycznego impulsu”, lecz raczej skonkretyzowaniem agresywnych poglądów nacjonalistycznych. To nie przypadek, że wielu przyszłych „bonzów” nazistowskich miało w swoich życiorysach odnotowane uczestnictwo we Freikorpsach. W trzech Powstaniach Śląskich $(1919,1920,1921)$ brało udział wielu narodowych socjalistów: Erich Koch, Gauleiter NSDAP w Prusach Wschodnich, nadprezydent prowincji Ostpreußen, administrator okręgu białostockiego i Komisarz Rzeszy na Ukrainie, znany ze swych antysłowiańskich (zwłaszcza antypolskich) przekonań aktywnie uczestniczył w walkach na Górnym Śląsku i w Zagłębiu Ruhry ${ }^{65}$. Podobną drogę odbył kolejny Alter Kämpfer, Gauleiter NSDAP w Hamburgu Karl Kaufmann — wziął udział w I wojnie, w 1920 roku jako członek Selbstschutz Oberschlesien, Sturmkompanie von Killinger uczestniczył w walkach o Górny Śląsk, później uczestnik walk w Zagłębiu Ruhry ${ }^{66}$. Wyższy Dowódca SS i Policji w Holandii SS-Obergruppenführer i generał policji Austriak Hanns Rauter wziął udział w I wojnie w armii austro-węgierskiej, a po jej zakończeniu uczestniczył w walkach z komunistami w Grazu, następnie w Karyntii, a w maju 1921 walczył z Polakami na Górnym Śląsku (Führer einer steirischen Legion in Oberschlesien beim Freikorps Oberland), został odznaczony Schlesischer Adler I Klasse ${ }^{67}$. SS-Obergruppenführer i generał policji, Wyższy Dowódca SS i Policji w Monachium Karl Freiherr von Eberstein, człowiek, który wprowadził Reinhardta Heydricha do SS, mógł pochwalić się przynależnością do Freikorpsów w Niemczech środkowych oraz w walkach o Górny Śląsk ${ }^{68}$. W walkach na Górnym Slasku uczestniczyli także Wyższy Dowódca SS i Policji w Protektoracie Czech i Moraw Karl Hermann Frank (najpierw z Czechami o Hulczyn, a później z Polakami o Górny Śląsk w ramach Powstań Śląskich) oraz być może pózniejszy potężny szef SD, następnie RSHA, p.o. Protektora Czech i Moraw Reinhardt Heydrich ${ }^{69}$. Wielu późniejszych

65 Gr1943, biogram Ericha Kocha, s. 270 oraz R. Meindl, Ostpreußens Gauleiter. Erich Koch — eine politische Biographie, Osnabrück 2007, s. 41.

66 Gr1943, biogram Karla Kaufmanna, s. 264; F. Bajohr, Gauleiter in Hamburg. Zur Person und Tätigkeit Karl Kaufmanns, ,Vierteljahreshefte für Zeitgeschichte” 1995, z. 2, s. 272.

67 Gr1943, biogram Hannsa Rautera, s. 340.

68 Gr1943, biogram Karla Freiherr von Ebersteina, s. 192.

69 Gr1943, biogram Karla Hermanna Franka, s. 208; R. Küpper, Karl Hermann Frank (18981946). Politische Biographie eines sudetendeutschen Nationalsozialisten, München 2010, s. 37; biogram Karla Hermanna Franka, s. 208; A. Schulz, G. Wegmann, D. Zienke, op. cit., s. 176. 
prominentnych dowódców SA wzięło udział w walkach o Górny Śląsk — Gauleiter NSDAP w Westfalii i Ruhrze, a następnie dowódca SA w latach 1926-1930 Franz von Pfeffer-Salomon wziął udział w I wojnie, założył niebawem Westfalisches Freikorps Pfeffer i wziął udział w walkach w Rzeszy, krajach bałtyckich, na Litwie, w Polsce, na Górnym Śląsku, później w Zagłębiu Ruhry ${ }^{70}$. Podobnie Edmund Heines urodzony w 1897 w Monachium: udział w Wielkiej Wojnie, w 1919 roku wraz z Freikorpsem Oberland uczestniczył w walkach w Monachium przeciwko tamtejszej republice rad; w latach 1919-1921 z Freikorpsem Roßbacha w krajach bałtyckich, w Zagłębiu Ruhry, na Górnym Śląsku. Heines, warto dodać, od 1921 był członkiem NSDAP i SA, po 1933 został prezydentem policji we Wrocławiu, był SA-Obergruppenführerem. Kresem jego kariery i życia była „,noc długich noży”" Ciekawe są koleje losu innego naówczas potężnego SA-Obergruppenführera, Hansa Petera von Heydebrecka. Urodził się w 1889 roku w Koszalinie, uczęszczał do szkoły kadetów w swoim rodzinnym mieście, wziął udział w I wojnie, w listopadzie 1918 stworzył Freikorps Heydebreck. Wraz ze swym korpusem ochotniczym odniósł niemałe sukcesy w III Powstaniu Śląskim: szturm na Kędzierzyn i jego zdobycie 5 czerwca 1921 (w Kędzierzynie jego oddział dokonał brutalnych mordów na ludności polskiej). Ze swego Freikorpsu stworzył podwaliny śląskich SA; później Heydebreck był dowódcą SA na Śląsku i Pomorzu, napisał wspomnienia Wir Wehr-Wölfe, został zamordowany w czasie puczu Röhma. Na krótki czas przed jego upadkiem i śmiercią miasto Kędzierzyn-Koźle, w uznaniu jego zasług dla tych terenów i Rzeszy, zostało przemianowane na Heydebreck (sic! $)^{72}$. Manfred Freiherr von Killinger walczył w I wojnie (służba w marynarce), następnie był dowódcą Sturmbataillon w Freikorpsie Ehrhardta, po jego rozwiązaniu pełnił kierownicze funkcje w Organisation Consul (OC). Wraz z ludźmi z Organisation Consul wziął udział w walkach o Górny Śląsk w 1921 roku (w jego oddziałach walczył Gauleiter Hamburga Kaufmann); później odsiadywał karę więzienia w związku z zamieszaniem w mord na Matthiasie Erzbergerze. Killinger od 1927 roku był związany z NSDAP, w 1933 roku został dowódca SA-Obegruppe I (obejmowała Meklemburgię, Pomorze, Berlin-Brandenburgię, Marchię Wschodnią, Śląsk etc.), w 1933 mianowany Komisarzem Rzeszy w Saksonii, w latach 1936-1938 był niemieckim konsulem generalnym

70 Gr1938, biogram Franza von Pfeffera, s. 340.

71 Gr1933, biogram Edmunda Heinesa, s. 197 oraz B. Cimała, Heines Edmund, [w:] Encyklopedia Powstań Ślaskich, s. 171.

72 Gr1933, biogram Hansa Petera von Heydebrecka, s. 205 oraz W. Lesiuk, Heydebreck Hans Adam Peter von, [w:] Encyklopedia Powstań Śląskich, s. 171-172. Znamienna i prorocza wydaje się fotografia zamieszczona w numerze 22 „Oberschlesien im Bild” z 1 czerwca 1934 roku (s. 8) w związku z przemianowaniem Kędzierzyna na Heydebreck - na fotografii widnieją Hans Peter von Heydebreck, Edmund Heines i Gauleiter NSDAP Schlesien oraz tamtejszy nadprezydent Brückner - wszystkich trzech zmiecie „noc długich noży”, Heydebreck i Heines stracą życie, ocalały Brückner niebawem straci stanowiska i będzie niewiele znaczył. „Oberschlesien im Bild” był cotygodniowym lokalnym dodatkiem do gliwickiej gazety „Oberschlesischer Wanderer”. 
w San Francisco, w latach 1938-1940 służba w Auswärtiges Amt, od 1940 był posłem niemieckim na Słowacji, od 1941 posłem niemieckim w Bukareszcie, awansowany do stopnia SA-Obergruppenführera ${ }^{73}$. Inny dowódca SA i zarazem dyplomata niemiecki w czasie II wojny światowej (poseł niemiecki w Budapeszcie) SA-Obergruppenführer Dietrich von Jagow mógł „pochwalić się” podobnym życiorysem: udział w I wojnie, w 1920 odszedł z wojska, uczestnik walk o Górny Śląsk w 1921 w Grenzschutzie ${ }^{74}$. Pochodzący z Pszczyny generał Karl Hoefer, odznaczony Pour le mérite, walczył z Polakami w Powstaniach Śląskich, wpierw jako dowódca dywizji Grenzschutzu, później jako dowódca górnośląskiego Selbstschutz. Himmler mianował sędziwego Hoefera (ur. 1862) SS-Oberführerem w 1936 roku. Hoefer zmarł w 1939 roku $^{75}$.

W walkach o Górny Śląsk w latach 1918-1921 wziął ponadto udział Emil Maurice, jeden z bliskich towarzyszy Hitlera w latach 20., a który po 1933 utracił wpływy, gdyż zajmował faktycznie niewiele znaczące stanowiska, choć dobrze opłacane, jak np. od 1936 Landeshandwerkmeister NSDAP Gau München-Oberbayern, ponadto był SS-Oberführerem i posłem do Reichstagu. Maurice, zegarmistrz z wykształcenia, w 1919 wstąpił do DAP, w tym samym roku wziął udział w obalaniu Republiki Rad w Monachium, a w 1921 uczestniczył w walkach na Górnym Śląsku, a następnie w puczu 8/9 listopada 1923 w Monachium ${ }^{76}$.

Spośród osób nieurodzonych na Śląsku, które wzięły udział w walkach polsko-niemieckich o tę krainę geograficzno-historyczną, a później piastowały wyższe i średnie stanowiska w Trzeciej Rzeszy, można wymienić nazistowskiego specjalistę ds. ekonomicznych, członka rady Deutsche Reichsbank i SS-Gruppenführera dr Franza Haylera (udział w obalaniu Republiki Rad w Bawarii w 1919, w walkach w Zagłębiu Ruhry w 1920, w walkach na Górnym Śląsku w 1921 — Góra św. Anny, później udział w pasywnym oporze i walka z separatystami w Palatynacie); SA-Oberführera i posła do Reichstagu Alfreda Eckarta (w 1919 roku walka z Freikorpsem Eulenburga na Górnym Śląsku, a w 1920

${ }^{73}$ Gr1943, biogram Manfreda Freiherr von Killingera, s. 267. Jako niemiecki konsul generalny w San Francisco von Killinger nie cieszył się zbyt dobrą opinią w USA. Opiniotwórczy „LIFE” pisał o nim: ,the brash and brutal Baron von Killinger, who had horrified California by inciting the German-American Bund to violence and had denounced German Tennis Ace von Cramm to Berlin for disparaging remarks the young player had made in a San Francisco home”, por. „LIFE” z 26 czerwca 1939, s. 27.

74 Gr1943, biogram Dietricha von Jagowa, s. 255.

75 E. Boberski, op. cit., s. 132-133. Autor pisał: „Von den oberschlesischen Generalen des Weltkrieges steht Karl Hoefer aus Pleß (1862 bis 1939) seiner Heimat am nächsten. Als »Tapferster der Tapferen« wurde der einarmige Regiments- und Divisionskommandeur im Weltkrieg mit dem Pour le mérite mit Eichenlaub und Schwertern ausgezeichnet. Nach dem Weltkrieg kommandierte er die Grenzschutzdivision in seiner Heimat und 1921 den oberschlesischen Selbstschutz". 20 kwietnia 1936 został SS-Oberführerem, por. Dienstaltersliste der Schutzstaffeln der NSDAP stand vom 1. Dezember 1938, Berlin 1938, s. 18-19. W 1938 roku ukazała się praca Hoefera o walkach o Górny Śląsk pt. Oberschlesien in der Aufstandszeit, 1918-1921. Erinnerungen und Dokumente.

76 Gr1943, biogram Emile Maurice'a, s. 298. 
w Zagłębiu Ruhry); Bawarczyka, posła do Reichstagu, pierwszego Gaugeschäftsführera NSDAP Gau Berlin-Brandenburg Franza Gutsmiedla (w 1919-1920 jako strzelec przy Freikorpsie Brigade Loewenfeld na Górnym Śląsku i w Zagłębiu Ruhry); SA-Standartenführera i posła do Reichstagu związanego od 1926 z NSDAP Bertholda Hella (udział w II Powstaniu Śląskim) ${ }^{77}$. Dalej można wymienić takich działaczy nazistowskich, jak SS-Oberführer, dowódca specjalnej jednostki SS złożonej z kłusowników, która „zasłynęła” zbrodniami na ludności w czasie Powstania Warszawskiego: dr Oskar Dirlewanger, który jako student Handelsschule w Mannheim walczył w czerwcu 1921 roku (ochotnik!) na Górnym Śląsku we Freikorpsie $\mathrm{Holz}^{78}$; NSKK-Brigadeführer, który związał się z NSDAP już w latach 20., Hubertus von Aulock był dowódcą tzw. Freikorps von Aulock, który został wykorzystany do tłumienia polskich strajków i demonstracji na Górnym Śląsku (styczeń-maj 1919) ${ }^{79}$; SS-Standartenführer działający w Dreźnie Georg Schroeder (udział w I wojnie, odejście z wojska, we Freikorpsach: 1919/1920 w krajach bałtyckich, 1920 Schwarze Reichswehr, walka z członkami Związku Spartakusa, w 1921 walki na Górnym Śląsku z Freikorpsem Roßbacha); działacz NSDAP w Karlsruhe dr inż Oskar Stäbel (w maju 1921 roku dowódca Selbstschutzu na Górnym Śląsku, odznaczony Schlesischer Adler II i I Klasse); SA-Standartenführer, dowódca SA w Lubece, tamtejszy Gauredner dr praw Georg Währer (Freikorps Eulenburg Grenzschutz, uczestnik puczu Kappa 1920, uczestnik III Powstania Śląskiego 1921 na Górnym Śląsku); SA-Brigadeführer związany z NSDAP od 1922 Oluf Christensen (udział w walkach o Górny Śląsk — w 1921 w III Powstaniu Śląskim, odznaczony Schlesischer Adler II Klasse); działacz nazistowski od lat 20., dowódca SA na Górnym Śląsku Bruno Czarnowski vel Scharno (udział w Grenzschutz Ost, w walkach w krajach bałtyckich, udział w puczu Kappa i w walkach o Górny Śląsk, z Górnego Śląska za swą działalność wydalony, członek Freikorpsu Roßbacha, posiadacz Baltenkreuz, Schlesischer Adler, Goldenes Ehrenzeichen der NSDAP); pracujący w Reichsleitung NSDAP, a później w Kancelarii Partii SS-Brigadeführer Helmuth Friedrichs (we Freikorpsach w latach 1920-1921, walki o Górny Śląsk, odznaczony Schlesischer Adler II i I Klasse); SA-Gruppenführer i szef jednego z urzędów (Amtschef) w Oberste SA-Führung Walther Heitmüller (od 1920 w Ehrhardt-Brigade, Organisation Consul, w 1921 udział w Selbstschutzie w walkach o Górny Śląsk, później uczestnik puczu monachijskiego z $8 / 9$ listopada 1923$)^{80}$.

77 Gr1943, biogram Franza Haylera, s. 233; Gr1938, biogram Alfreda Eckarta, s. 194; Gr1933, biogram Franza Gutsmiedla, s. 189; Gr1933, biogram Bertholda Hella, s. 199;

78 H. Auerbach, Die Einheit Dirlewanger, „Vierteljahreshefte für Zeitgeschichte” 1962, z. 3 , s. 251.

79 E. Mendel, W. Lesiuk, Freikorps von Aulock, [w:] Encyklopedia Powstań Ślaskich, s. 132.

${ }^{80}$ Gr1933, biogram Georga Schroedera, s. 317; Gr1933, biogram dr Oskara Stäbela, s. 335; Gr1936, biogram dr Georga Währera, s. 340; Gr1943, biogram Olufa Christensena, s. 177; Gr1943, biogram Brunona Scharno, s. 363; Gr1943, biogram Helmutha Friedrichsa, s. 211; Gr1943, biogram Walthera Heitmüllera, s. 236. 
Można też wymienić zawodowego oficera SA, który służył również w Wehrmachie jako podpułkownik i odbył kampanię wrześniową w 1939, SA-Obergruppenführera Kurta Kühme (udział w I wojnie, od końca wojny do maja 1920 dowódca Freikorpsu na Śląsku, w maju 1920 dobrowolnie odszedł z wojska jako major, w 1921 udział w III Powstaniu Śląskim — walki wokół Kluczborka i Olesna), SA-Brigadeführera Heinza Lampe (udział w I wojnie, po jej zakończeniu członek Eiserne Division i walki w krajach bałtyckich, następnie dowódca kompanii przy Grenzschutz Oberschlesien w walkach o Górny Śląsk, później w Ehrhardt-Brigade i walki w Ruhrze); SA-Oberführera Waltera Neula (udział w I wojnie, w 1919 udział w walkach w krajach bałtyckich i na Górnym Śląsku, odznaczony Schlesischer Adler II Klasse). Podobnymi epizodami walk o Górny Śląsk oraz w innych częściach Niemiec czy Europy mogli się pochwalić Kreisleiter NSDAP w Wiesbaden oraz tamtejszy burmistrz, SS-Standartenführer Felix Piékarski (udział w I wojnie, po jej zakończeniu w latach 1919-1921 członek Freikorps „Lützow”, udział w Grenzschutz Schlesien i w walkach na Górnym Śląsku, w puczu Kappa oraz w walkach w Ruhrze); NSKK-Gruppenführer Eberhard Ponndorf (udział w I wojnie, następnie Freikorps Maercker, z którym uczestniczył w walkach z komunistami w Halle, Lipsku i Brunszwiku oraz z Polakami na Górnym Śląsku; uczestnik puczu Kappa); działacz HJ (Obergebietsführer), NSDAP Richard Reckewerth (udział w I wojnie, później uczestnik puczu Kappa, uczestnik walk o Górny Śląsk z Freikorpsem Hasse, odznaczony Schlesischer Adler II i I Klasse); pracownik Reichsleitung NSDAP i Kancelarii NSDAP Martin Seidel (udział w I wojnie, później Freikorpsy w Niemczech oraz na Górnym Śląsku), SS-Standartenführer, doktor medycyny, prezydent policji w Rostocku Hans-Eugen Sommer (w 1921 wraz z Freikorpsem Roßbacha udział w walkach z Polakami o Górny Śląsk, odznaczony Schlesischer Adler II Klasse) czy Kreisleiter NSDAP w Bremie i funkcjonariusz Gau NSDAP Weser Ems Kurt Thiele (w 1921 wraz z 30 zwerbowanymi ochotnikami udał się na Górny Śląsk do walki z Polakami), działacz wschodniopruskiej NSDAP, od 1933 zastępca Kocha jako nadprezydenta Prus Wschodnich Hermann Bethke (żołnierz Freikorpsu na Górnym Śląsku) ${ }^{81}$.

W walkach na Górnym Śląsku wzięło udział wielu późniejszych nazistów urodzonych na Śląsku, wychowanych i związanych ze Śląskiem, częstokroć także po 1933 roku. Helmuth Brückner, który związany był z NSDAP od lat 20., w 1925 roku założył śląską NSDAP i był długoletnim Gauleiterem NSDAP na Śląsku, uczestniczył w I wojnie, w 1921 jako członek Ib-Gruppe Nord w niemieckim Selbstschutzu na Górnym Śląsku (III Powstanie Śląskie), odznaczenia

81 Gr1943, biogram Kurta Kühme, s. 281; Gr1943, biogram Heinza Lampe, s. 285; Gr1943, biogram Waltera Neula, s. 314; Gr1943, biogram Felixa Piékarskiego, s. 328; Gr1943, biogram Eberharda Ponndorfa, s. 331; Gr1943, biogram Richarda Reckewertha, s. 341; Gr1943, biogram Martina Seidla, s. 387; Gr1943, biogram dr Hansa-Eugena Sommera, s. 392; Gr1943, biogram Kurta Thiele, s. 407. O H. Bethke, zob. R. Meindl, Ostpreußens Gauleiter..., s. 108. 
Schlesischer Adler I i II Klasse i Eichenkranz. Jego kariera dobiegła końca po tzw. puczu Röhma ${ }^{82}$. Walką z Polakami (w latach 1919-1920 w Grenzschutzu na Śląsku, odznaczony Schlesischer Adler I Klasse) mógł się poszczycić wspomniany już SS-Brigadeführer Albrecht Schmelt, który nota bene stał na czele tzw. Organisation Schmelt wykorzystującej Żydów do niewolniczej pracy na Śląsku ${ }^{83}$. Współzałożyciel Narodowosocjalistycznego Związku Lekarzy, Reichsärzteführer, SA-Obergruppenführer dr med. Gerhard Wagner (urodzony na terenie dzisiejszego Chorzowa) wziął udział w I wojnie, następnie był członkiem Freikorpsu von Epp, później Freikorps Oberland, z którym wziął udział w Powstaniach Śląskich (niebawem przywódca Niemców górnośląskich) ${ }^{84}$. Można tu wskazać na takie postacie jak wspomniany wyżej Josef Adamczyk/Adams (uczestnik walk polsko-niemieckich o Górny Śląsk 1918-1921 [Freikorps-, Abstimmungs- und Selbstschutzkämpfer], odznaczony Schlesischer Adler I i II Klasse); oficer SA w SA-Gruppe Schlesien, a w latach II wojny m.in. dowódca Waffen-SS w Protektoracie Czech i Moraw SS-Gruppenführer i generał-porucznik Waffen-SS Carl hrabia von Pückler-Burghaus pochodzący z Wrocławia (udział w I wojnie, odszedł w 1919 roku z wojska, udział w walkach o Górny Śląsk w 1921 roku); szef sztabu SA-Gruppe Schlesien w 1931, SA-Gruppenführer Hans Hayn z Legnicy (1919 kupiec we Wrocławiu; w 1921 w ramach Selbstschutz Oberschlesien walczył o Górny Śląsk z Polakami; w 1923 roku współpraca z Albertem Leo Schlageterem w Zagłębiu Ruhry); dowódca SA na Śląsku (SA-Gruppe Schlesien) od 1937 Heinrich Georg hrabia Fink von Finkenstein (członek Freikorps „Sturmabteilung Schlichtingsheim”, „Dritte Marine Brigade von Loewenfeld” i „Bataillon Schlageter" - udział w 3 Powstaniach Śląskich, ponadto walki w Ruhrze i udział w puczu Kappa); związany ze śląską NSDAP, SA-Oberführer wywodzący się spod Wrocławia Erich Hasse (do lipca 1919 w śląskim Freikorpsie [Grenzschutz, ochotniczy oddział Arndt], otrzymał Schlesischer Adler II Klasse); Herbert Barthel (udział w I wojnie, później we Freikorpsach na Litwie i w Prusach Wschodnich oraz w Grenzschutzu na Śląsku do kwietnia 1920); SA-Standartenführer Paul Binus urodzony w Raciborzu (w 1919 i w 1921 roku aktywny udział w walkach

82 Gr1933, biogram Helmutha Brücknera, s. 145.

83 Gr1943, biogram Albrechta Schmelta, s. 369. O Organizacji Schmelt pisał szczegółowo komendant KL Auschwitz Rudolf Höß, zob. Autobiografia Rudolfa Hössa komendanta obozu oświęcimskiego, Warszawa 1989, s. 205-207.

${ }^{84}$ Gr1938, biogram Gerharda Wagnera, s. 441. W „Oberschlesischer Heimatkalender für das Jahr 1943” o Wagnerze napisano m.in. „Aus der Reihe der großen Mediziner oberschlesischer Herkunft seien zwei Männer erwähnt: Adalbert Czerny aus Schakowa [...] und Gerhard Wagner aus Königshütte (1888 bis 1939). [...] Dr med. Gerhard Wagner hat nach seiner Rückkehr von der Front des Weltkrieges im Freikorps Epp und für seine Heimat im Oberschlesischen Selbstschutz mitgekämpft. Er gehört zu den ältesten Gefolgsmännern des Führers und Gründern des Nationalsozialistischen Deutschen Ärztebundes. Der Führer berief ihn 1933 zum ersten Reichsärzteführer des neuen Deutschlands", por. E. Boberski, op. cit., s. 127-128. 
o Górny Śląsk przeciwko Polakom; odznaczony Schlesischer Adler II i I Klasse) ${ }^{85}$. Kolejnymi postaciami, które wypadałoby wymienić, mogą być Gauamtsleiter NSDAP na Śląsku, urodzony w Bytomiu Dr Fritz Kleiner (organizator w Niemczech „Vereinigte Verbände heimattreuer Oberschlesier” na rzecz plebiscytu na Górnym Śląsku, odznaczony Schlesischer Adler II i I Klasse, udział w walkach na Górnym Śląsku, ścigany i wydalony przez aliantów z Górnego Śląska); Kreisleiter NSDAP w Zabrzu i nadburmistrz Zabrza Max Fillusch (udział w walkach o Górny Śląsk), pochodzący z Opola działacz śląskiej NSDAP, Kreisleiter NSDAP kolejno w Zabrzu, Trzebnicy i Lubinie Alfred Jonas (w 1921 ochotnik w Selbstschutz w walkach na Górnym Śląsku, Schlesischer Adler II i I Klasse); urodzony we Wrocławiu działacz śląskiej NSDAP już od 1925 roku, jej Gauorganisationsleiter, a po 1941 pracujący w Kancelarii Partii w Monachium Bruno Müller-Reinert (udział w I wojnie, później w Grenzschutz na Górnym Śląsku w 1919, udział jako ochotnik w walkach w 1921 [III Powstanie Śląskie]); jeden z twórców NSDAP w Gliwicach, Kreisleiter NSDAP w Gliwicach, następnie w Oleśnie-Dobrodzieniu, a od 1939 Kreisleiter Raciborza Richard Preiss (udział jako ochotnik w Maschinen-Gewehr-Kompanie von Watzdorf w walkach o Górny Śląsk, ranny, odznaczony Schlesischer Adler II i I Klasse); pochodzący z Wrocławia dowódca wielu jednostek NSKK na Śląsku, NSKK-Obergruppenführer Heinrich-Christian Schäfer-Hansen (1920 udział w puczu Kappa, 1921 udział w walce o Górny Śląsk z Polakami); zastępca Gauleitera Gau Halle-Merseburg, NSKK-Oberführer Georg Tesche (w 1919 we Freikorpsie von Aulock, walki o Górny Śląsk, Schlesischer Adler II i I Klasse, w 1921 w batalionie Guttentag, walki w III Powstaniu Śląskim $)^{86}$.

Walki polsko-niemieckie toczyły się również w Wielkopolsce (1918-1919). Wspomniany już Arno Manthey (urodzony w Wielkopolsce, w Szubinie), po 1933 SA-Obergruppenführer i dowódca SA-Grupe Ostmark wziął udział w I wojnie, następnie w styczniu 1919 roku w powiecie nadnoteckim Szubin-Bydgoszcz (Netzekreis Schubin-Bromberg) organizował opór niemiecki przeciwko Polakom (,gegen aufständischen Polen") ${ }^{87}$. Wspomniany także wcześniej SA-Obergruppenfüh-

85 Gr1933, biogram Josefa Adamczyka, s. 124; Gr1933, biogram Carla hrabiego von Pückler-Burghausa, s. 226; Gr1933, biogram Hansa Hayna, s. 196; Gr1943, biogram Heinricha Georga hrabiego Fink von Finkenstein, s. 203; Gr1932, biogram Ericha Hasse, s. 91; Gr1943, biogram Herberta Barthela, s. 152; Gr1943, biogram Paula Binusa, s. 159.

${ }^{86}$ Gr1936, biogram Fritza Kleinera, s. 206; G1943, biogram Maxa Filluscha, s. 202; Gr1943, biogram Alfreda Jonasa, s. 257; Gr1943, biogram Brunona Müller-Reinerta, s. 308; Gr1943, biogram Richarda Preissa, s. 334; Gr1943, biogram Heinricha-Christiana Schäfer-Hansena, s. 362; Gr1943, biogram Georga Tesche, s. 406.

${ }^{87}$ Gr1938, biogram Arno Mantheya, s. 309 oraz artykuł SA-Obergruppenführer Manthey $\%$ Der Führer der SA-Gruppe Oder im Osten gefallen, „Ostdeutscher Beobachter” nr 246, 5 września 1941 roku, gdzie napisano, że ,schied er [Arno Manthey - W.K.] nach Kriegsende im Dezember 1918 aus dem Heeresdienst aus. Bald darauf legte Manthey wiederum den grauen Rock an, um im Osten polnischer Raubgier und Willkür entgegenzutreten. Er sammelte Bauern und Arbeiter um sich und bildete vor Bromberg die erste Widerstandsfront, an der alle polnischen Durchbruchsversuche scheiterten. Wie sehr Manthey mit seiner Truppe Seele des deutschen Widerstandes und 
rer Hans Peter von Heydebreck miał wraz ze swym Freikorps von Heydebreck walczyć przeciwko Polakom w Powstaniu Wielkopolskim ${ }^{88}$. Podobnie szef DAF (Gauobmann DAF) w Gau NSDAP Essen Fritz Johlitz (pochodzący z Piły) walczył w I wojnie, w latach 1918-1920 we Freikorpsie przeciwko Polsce (Poznańskie) (,im Freikorps gegen Polen [Posen]”). W walkach w Poznańskiem, ale także na Górnym Śląsku w ramach Grenzschutz Ost miał się wykazać SS-Brigadeführer i generał major Waffen-SS i policji, dowódca Waffen-SS w Protektoracie Czech i Moraw Alfred Karrasch ${ }^{89}$.

Wielu nazistów służyło w jednostkach Grenzschutz Ost i tym sposobem mogli oni walczyć przeciwko Polakom i/lub wchodzić w jakiejś kontakty z nimi. Można tu podać SA-Brigadeführera i prezydenta policji w Gliwicach Hansa Ramshorna (od stycznia do sierpnia 1919 roku w Grenzschutz Ost w Toruniu i okolicach, później w państwach bałtyckich, następnie Marinebrigade von Loewenfeld i walki w Zagłębiu Ruhry w 1920); gubernatora Dystryktu Lublin w czasie okupacji niemieckiej Polski w latach II wojny Ernsta Zörnera (udział w I wojnie, później Grenzschutz Ost w Gdańsku do 1 października 1919). Służbę w Grenzschutz Ost podali w swych życiorysach: prezydent rejencji poczdamskiej, SS-Oberführere Gottfried hrabia von Bismarck-Schönhausen; następca Adolfa Hühnleina na stanowisku NSKK-Korpsführera Erwin Kraus (udział w I wojnie, w latach 1919-1920 we Freikorps Berlin, następnie członek Grenzschutz Ost oraz uczestnik walk w krajach bałtyckich); także SS-Obergruppenführer Werner Lorenz, szef Głównego Urzędu SS ds. Niemców etnicznych (członek Grenschutz Ost po zakończeniu I wojny); nazistowski specjalista ds. rolnictwa, od 1936 dyrektor ministerialny w Ministerstwie Wyżywienia i Rolnictwa Rzeszy oraz Prus, SS-Gruppenführer oraz SA-Gruppenführer Hans-Joachim Riecke (udział w I wojnie, w 1919 Freikorps i Grenzschutz); doktor medycyny dentystycznej, NSKF-Gruppenführer, major lotnictwa Otto Zimmermann (udział w I wojnie, później do 1919 Grenzschutz); związany z partią od lat 20., dowódca SA w Westfalii, SA-Gruppenführer Franz Bauer (udział w I wojnie, następnie Grenzschutz Ost $)^{90}$. W Grenzschutz służyło także jeszcze paru wysokich oficerów SS: szef Amt C w SS-WVHA SS-Obergruppenführer Hans Kammler, SS-Obergruppen-

wie sehr er bei den Polen gehaßt war, das beweist die Tatsache, daß diese eine hohe Belohnung auf seinen Kopf ausgesetzt hatten”. Wypada dodać, że Manthey w 1933 jako SA-Brigadeführer został dowódcą SA-Brigade 8 w Pile. O udziale Mantheya w walkach z Polakami (np. obrona Szubina) pisał również Antoni Czubiński, por. A. Czubiński, Powstanie Wielkopolskie 1918-1919. Genezacharakter-znaczenie, Poznań 2002, s. 208.

88 W. Lesiuk, Heydebreck Hans Adam Peter von, [w:] Encyklopedia Powstań Śląskich, s. 171.

89 Gr1943, biogram Fritza Johlitza, s. 257; A. Schulz, G. Wegmann, D. Zienke, op. cit., s. 469.

90 Gr1933, biogram Hansa Ramshorna, s. 281; Gr1933, biogram Ernsta Zörnera, s. 315; Gr1943, biogram Gottfrieda hrabiego von Bismarck-Schönhausen, s. 160; Gr1943, biogram Erwina Krausa, s. 277; Gr19432, biogram Wernera Lorenza, s. 292; Gr1943, biogram Hansa-Joachima Riecke, s. 351; Gr1943, biogram dr Ottona Zimmermanna, s. 438; Gr1943, biogram Franza Bauera, s. 153 . 
führer Udo von Woyrsch, jeden z współzałożycieli śląskich SS, później dowódca SS na Śląsku (jeszcze przed 1933 rokiem), następnie w Dreźnie (von Woyrsch być może wziął udział w Powstaniach Śląskich); Dowódca SS i Policji w Lublinie SS-Gruppenführer Jakob Sporrenberg (ochotnik w Grenzschutz Ost i Freikorps II. Landesschützenbrigade; zdaniem K. Grünberga i Sz. Datnera Sporrenberg brał udział w Powstaniach Śląskich), SS-Brigadeführer Horst Hoffmeyer, SS-Brigadeführer Richard Herrmann ${ }^{91}$. SA-Oberführer w Prusach Wschodnich Claus von Platen po zakończeniu I wojny działał we wschodniopruskim Freikorpsie; członkiem szkoły podoficerskiej w Kwidzyniu (Marienwerder) i Marinebrigade-Ehrhardt w latach 1919-1920 był SA-Gruppenführer w OSAF Rudolf Michaelis. Od grudnia 1918 do października 1919 służył w Freiwiliges-Bataillon I Brigade Grodno (Freikorps „Brigadesüdlitauen”) w Grodnie dowódca Policji Porządkowej (Orpo) w Dystrykcie Lublin, następnie Dowódca SS i Policji w Równem, a później w Rostowie oraz Wyższy Dowódca SS i Policji na Kaukazie Gerret Korsemann, odpowiedzialny za eksterminację Żydów na obszarze jego władzy zwierzchniej jako dowódcy $\mathrm{SS}^{92}$.

W wypadku osób o polsko brzmiących nazwiskach kwestia przedstawia się dość kontrowersyjnie i może być wielce złudna, ale fakt posiadania polsko brzmiących nazwisk przez niektórych nazistowskich dostojników mógł - być może - świadczyć o tym, że mieli polskie korzenie lub w jakiś inny sposób ich przodkowie „stykali” się z polskością. Niektórym nazistowskim funkcjonariuszom bardzo „wadziło” polskie nazwisko lub polski człon w nazwisku — niektórzy zmieniali przez to nazwiska na bardziej „niemieckie"93.

Wybitny znawca dziejów nazizmu i Niemiec, profesor Franciszek Ryszka pisał o lokalnych działaczach nazistowskich ze Śląska: „Polskie brzmienie nazwisk

91 O Kammlerze: A. Schulz, G. Wegmann, D. Zienke, op. cit., s. 441-443; Gr1943, biogram Udo von Woyrscha, s. 435 oraz M. Cygański, SS w pruskich prowincjach Śląska ..., s. 209 n.; Gr1943, biogram Jakoba Sporrenberga, s. 395 oraz K. Grünberg, op. cit., s. 206 i S. Datner, Niemiecki okupacyjny aparat bezpieczeństwa w okręgu białostockim (1941-1944) w świetle materiałów niemieckich (opracowania Waldemara Macholla), „Biuletyn Głównej Komisji Badania Zbrodni Hitlerowskich w Polsce" XV, 1965, s. 15; o Hoffmeyerze i Herrmanie, zob. A. Schulz, G. Wegmann, D. Zienke, op. cit., s. 169, 314-315. Hoffmeyer był działaczem zarówno VDA (Verein für das Deutschtum im Ausland), jak i BDO (Bund Deutscher Osten), zaś od listopada 1939 do lutego 1940 już jako SS-Standartenführer kierował operacją przesiedlenia wołyńskich i galicyjskich Niemców do Wielkopolski, por. G. Jérome, op. cit., s. 56.

92 Gr1943, biogram Clausa von Platena, s. 276; Gr1943, biogram Rudolfa Michaelisa, s. 302; odnośnie Korsemanna, A. Schulz, G. Wegmann, D. Zienke, op. cit., s. 570.

93 Można tu zastosować słynny teoremat Williama Thomasa „If men define situations as real, they are real in their consequences" (W.I. Thomas, D.S. Thomas, The Child in America. Behavior problems and programs, New York 1928, s. 572) - tzn. nie było istotne, czy niektórzy nazistowscy prominenci o polsko brzmiących nazwiskach naprawdę mieli polskie korzenie, lecz oni sami odczuwali polsko brzmiące nazwisko jako c i ę ż a r/p r o ble m i stąd zmieniali nazwiska na bardziej niemieckie (definiowali sytuację jako rzeczywistą i była ona rzeczywista w swych konsekwencjach). 
nie powinno nikogo dziwić. Rezultatem wynarodowienia w pierwszym lub drugim pokoleniu była bardzo często udramatyzowana nienawiść do narodu przodków"94. Można tu podać przypadki potężnego prominenta SS, SS-Obergruppenführera Ericha von dem Bach-Żelewskiego, który zmienił nazwisko ${ }^{95}$, czy działacza nazistowskiego ze Śląska, wspomnianego już Josefa Adamczyka, który zmienił niebawem nazwisko na Adams lub Bruno Czarnowskiego, który stał się Bruno Scharno. Można wymienić takich prominentów nazistowskich jak Reichsredner NSDAP, od 1941 Reichsamtsleiter w Reichspropagandaleitung NSDAP w Berlinie, SA-Oberführer i współpracownik Goebbelsa Werner Studentkowski (ur. 20 września 1903 w Kijowie); wspomniany już kat krajów bałtyckich (m.in. Dowódca SS i Policji w Kownie) Lutz Wysocki; Gaugeschäftsführer Gau Brandenburg od 1936, SS-Oberführer i nadburmistrz Frankfurtu nad Odrą Victor von Podbielski; Kreisleiter NSDAP oraz burmistrz Wiesbaden, SS-Standartenführer Felix Piékarski; Kreisleiter NSDAP i starosta w Marburgu (Hesja) Hans Krawielitzki; SS-Standartenführer i prezydent policji w Poczdamie (zastąpił hrabiego von Helldorfa) Heinrich von Dolega-Kozierowski; funkcjonariusz Gauleitung NSDAP Berlin i SS-Standartenführer Karl Spiewok; SA-Gruppenführer w Sztabie OSAF Elhard von Morozowicz; Reichsoberrevisor w Reichsleitung NSDAP w Monachium Karl Janowsky; SA-Standartenführer z Sudetów Ernst Peschka ${ }^{96}$. Polskobrzmiące nazwisko posiadali także SS-Oberführer, komendant KL Sachsenhausen Hermann Baranowski ${ }^{97}$; funkcjonariusz Gestapo (był kierownikiem Abwehramt, który działał w okresie Dielsa i ostał się na stanowisku

${ }^{94}$ F. Ryszka, Polityka hitlerowska na Ślasku (1933-1945). Uwagi ogólne i postulaty badawcze, „Studia Śląskie” 10, 1966, s. 18.

95 Decyzją prezydenta rejencji we Wrocławiu z dnia 28 listopada 1940 roku uzyskał on zgodę na oficjalną zmianę nazwiska na von dem Bach (usunął człon -Żelewski, który był jednoznacznie polsko brzmiący). Władysław Bartoszewski napisał, że: ,[t]emu ważnemu i radosnemu wydarzeniu w swoim życiu poświęcił nawet obszerny osobisty list do Himmlera (z 4 grudnia 1940 r.), w którym opisuje m.in., jak bardzo cierpiała jego matka, gdy w wyniku powstania państwa polskiego po pierwszej wojnie światowej, grób ojca pochowanego na cmentarzu w Wejherowie znalazł się na polskiej ziemi”. Zdaniem autora polski członek nazwiska von dem Bacha wywodził się od nazwy rodowego majątku tj. wsi Zelewo (Seelau) na Kaszubach nieopodal Wejherowa, a jego ojciec, Oskar von Zelewski poległ w czasie walk nad Narwią w 1915 roku jako oficer rezerwy, zob. W. Bartoszewski, Prawda o von dem Bachu, Warszawa-Poznań 1961, s. 11.

${ }^{9}$ Gr1943, biogram Wernera Studentkowskiego, s. 403; Gr1943, biogram Lutza Wysockiego, s. 436; Gr1943, biogram Victora von Podbielskiego, s. 330; Gr1943, biogram Felixa Piékarskiego, s. 328; Gr1943, biogram Hansa Krawielitzkiego, s. 277; Gr1943, biogram Heinricha von Dolega-Kozierowskiego, s. 188; Gr1943, biogram Karla Spiewaka, s. 316; Gr1933, biogram Elharda von Morozowicza, s. 260; Gr1938, biogram Karla Janowsky, s. 263; Gr1943, biogram Ernesta Peschki, s. 324.

97 Hermann Baranowski (ur. 11 czerwca 1884), członek NSDAP (nr 345 321) i członek SS (nr 24 009), który został mianowany SS-Oberführerem 9 listopada 1938. Baranowski jako komendant obozu koncentracyjnego w Sachsenhausen był wzorem i ,idolem” dla późniejszego komendanta Oświęcimia Rudolfa Hößa, por. Dienstaltersliste der Schutzstaffeln der NSDAP stand vom 1. Dezember 1938, Berlin 1938, s. 24. 
po przyjściu Heydricha) i SD, SS-Oberführer dr Günther Patschowsky, który później zmienił nazwisko na Palten ${ }^{98}$. Wysoki funkcjonariusz Gau Oberschlesien, Gaustabsamtsleiter Paul Roden do 1936 roku nosił nazwisko Rorzyczka ${ }^{99}$. Można też wymienić postać SS-Standartenführera o nazwisku Heinz Sawatzki, który w 1938 był dowodcą 78. SS-Standarte czy SS-Standartenführera Wilhelma Janowsky ${ }^{100}$. W spisach oficerów SS (Dienstaltersliste der SS) z różnych lat można natrafić na polsko brzmiące nazwiska, na przykład SS-Brigadeführer Leo von Falkowski, SS-Standartenführer Wilhelm von Woikowski-Biedau, działający w GG SS-Standartenführer Dr Hermann Senkowsky, SS-Standartenführer Egon Dalski czy SS-Standartenführer Wladimir von Pawlowski.

Część z wielu wymienionych osób, które weszły w różny sposób w kontakt z Polakami, z Polską, z polskością, w latach II wojny światowej znów działała na ziemiach polskich.

Arthur Greiser właściwie już od czasów gdańskich, kiedy pełnił tam ważne funkcje partyjne (zastępca Gauleitera Forstera) oraz urzędowe (m.in. przewodniczący Senatu Wolnego Miasta Gdańska), „tkwił” w sprawach polskich. W październiku 1939 roku został Gauleiterem i Reichsstatthalterem Reichsgau Wartheland - zapisał się na kartach historii jako zbrodniarz odpowiedzialny za terror, egzekucje, mordy, wypędzenia do GG, grabież nieruchomości, przymusową germanizację itd. ludności polskiej i żydowskiej ${ }^{101}$.

Ludwik Wolff, dawny przywódca mniejszości niemieckiej w Łodzi w latach II RP, jako Kreisleiter NSDAP w Łodzi zapisał niechlubną kartę. M. Cygański napisał, że „wszystkie publiczne wystąpienia Wolffa cechował tępy fanatyzm i zażarta nienawiść do Polaków. W każdym niemal przemówieniu zapowiadał »ostateczne rozwiązanie« polskiego i żydowskiego problemu w Łodzi”102. Po wojnie Wolff był znanym działaczem ziomkostwa w RFN „Wisła-Warta”"103. $\mathrm{Na}$ terenie Łodzi i powiatu łódzkiego działali inni volksdeutsche łódzcy — Wilhelm Kretschmar, SA-Oberführer i dowódca SA w Łodzi czy Kreisleiter NSDAP

98 Dr Palten (ur. 3 marca 1903), członek NSDAP (nr 566 217) i członek SS (nr 40 064) był funkcjonariuszem SD, a później RSHA — mianowany 21 czerwca 1944 roku SS-Brigadeführerem, por. Dienstaltersliste der Schutzstaffel der NSDAP. Stand vom 9 November 1944 (Berlin 1944, s. 22) oraz M. Wildt, Generation des Unbedingten. Das Führungskorps des Reichssicherheitshauptamtes, Hamburg 2003, s. 221.

99 R. Kaczmarek, Pod rządami gauleiterów. Elity i instancje władzy w rejencji katowickiej w latach 1939-1945, Katowice 1998, s. 109.

100 Heinz Sawatzki, ur. 6 lutego 1904, członek NSDAP (nr 189 633) i SS (nr 6 000), awansowany do stopnia SS-Standartenführera 20 kwietnia 1936, zob. Dienstaltersliste der Schutzstaffeln der NSDAP stand vom 1. Dezember 1938, Berlin 1938, s. 28-29. Wilhelm Janowsky, ur. 5 sierpnia 1905, członek NSDAP (nr 127 234) i SS (nr 3 828), w 1938 oficer przy SS-Hauptamt, awansowany na SS-Standartenführera 20 kwietnia 1937, zob. ibidem, s. 32-33.

101 C. Łuczak, op. cit., s. 43-48 oraz C. Epstein, op. cit., s. 125-264.

102 M. Cygański, $Z$ dziejów okupacji..., s. 140.

103 K. Grünberg, op. cit., s. 545. 
w powiecie łódzkim, a później starosta Herbert Mees, o którym przywoływany już M. Cygański pisał:

Volksdeutsch ten należał do największych prześladowców Polaków i Żydów oraz najgorliwszych realizatorów okupacyjnej polityki narodowościowej. Jednym z licznych tego dowodów był współudział Meesa w masowych rozstrzeliwaniach Polaków w Zgierzu [...]. Mees prześladował też volksdeutschów zgierskich, utrzymujących przed wojną bliższe stosunki z ludnością polską lub żydowską ${ }^{104}$.

Erich von dem Bach-Żelewski został w 1938 roku mianowany Wyższym Dowódcą SS i Policji na Śląsku z siedzibą we Wrocławiu. Później pełnił podobną funkcję w ZSRR oraz był szefem jednostek do zwalczania partyzantów. Do „spraw polskich” powrócił jesienią 1944 roku, kiedy został naczelnym dowódcą jednostek niemieckich walczących z powstańcami warszawskimi. W czasie rozmów o zawieszenie broni z polską delegacją w Ożarowie przyznał się do swoich kontaktów z polskością. Pułkownik Kazimierz Iranek-Osmecki wspominał o polskich ,akcentach” w życiu von dem Bacha, które ten chętnie przywołał w czasie ich rozmowy w październiku 1944 w Ożarowie. Polski oficer napisał:

Bach urodził się na wsi pod Tczewem. Matka jego była Polką. Osierocony we wczesnym dzieciństwie, nie pamięta rodziców. Wychowany był przez księdza Polaka, proboszcza jednej $\mathrm{z}$ wiejskich parafii, pobliskiej jego miejsca urodzenia. Okres ten wspomina z głębokim wzruszeniem, pamięta jeszcze z tego czasu kilka polskich słów i pieśni kościelnych, które zacytował. W jego interpretacji brzmiało to niezupełnie po polsku, ale zrozumiale: „Niek bendzie pokwalony Jezas Krystas” i strofa jednej z pieśni nieszpornych. Jako młody chłopiec wstąpił do korpusu kadetów. Chrzest ogniowy przeszedł w pierwszej wojnie światowej na froncie wschodnim na ziemiach polskich. Wkrótce potem przeniesiony na front zachodni, pozostał tam do końca wojny. Stosunki polskie studiował i wydaje mu się, że zna je dobrze.

Dalej von dem Bach chwalił polskie podziemie, AK, Powstańców Warszawskich, a zwłaszcza kobiety i ich odwagę ${ }^{105}$. Choć można uznać wiarygodność opowiadań Niemca, to należy jednak pamiętać, że von dem Bach uczynił to „na pokaz”, bo chyba nigdy jakoś specjalnie nie chwalił się tym na forum „wielkiej Rzeszy" i w kręgach nazistowskich. Władysław Bartoszewski wyliczył zbrodnie von dem Bacha, za które nigdy nie został ukarany: jako HSSPF Südost był odpowiedzialny za akcję przymusowej germanizacji i wysiedleń Polaków i Żydów ze Śląska (np. wysiedlenie ok. 20 tys. Polaków z powiatu żywieckiego); był inicjatorem utworzenia KL Auschwitz oraz wydał nakaz zabijania na miejscu mężczyzn napotkanych na przedpolu tego obozu i aresztowania kobiet i dzieci. Ponadto zarządził wysiedlenia miejscowej ludności w promieniu 5 km wokół obozu oświęcimskiego oraz pozbawienie jej mienia. Jako Chef der Bandenkampfverbände ponosił odpowiedzialność za egzekucje odwetowe za pomoc partyzantom

104 M. Cygański, Z dziejów okupacji..., s. 107.

105 K. Iranek-Osmecki, Powołanie i przeznaczenie. Wspomnienia oficera Komendy Głównej $A K$, Warszawa 2004, s. 461. 
na terenie GG, jako dowódca „Korpsgruppe von dem Bach” (6 VIII-6 X 1944) w Powstaniu Warszawskim był odpowiedzialny za zbrodnie na ludności cywilnej oraz jeńcach, za celowe niszczenie warszawskich szpitali, świątyń, domów, pomników etc. czy wywiezienie ok. 50 tys. ludności z Warszawy do obozów koncentracyjnych w sierpniu i wrześniu $1944^{106}$. Arthur Seyss-Inquart był jednym z najważniejszych funkcjonariuszy nazistowskich na ziemiach polskich do maja 1940 (zastępca Franka jako generalnego gubernatora), kiedy został Komisarzem Rzeszy w Holandii. Współodpowiedzialny za wiele zbrodni niemieckich w tamtym czasie (eksterminacja polskiej inteligencji, Żydów, deportacje etc.). Przez niego, zdaniem Cz. Madajczyka, SS chciała zdobyć silną pozycję w $\mathrm{GG}^{107}$. Wilhelm Koppe jesienią 1939 roku został Wyższym Dowódcą SS i Policji w Kraju Warty; jesienią 1943 Koppe objął schedę po Krügerze w GG jako Wyższy Dowódca SS i Policji oraz sekretarz stanu ds. bezpieczeństwa. W GG względnie harmonijnie współpracował z Hansem Frankiem ${ }^{108}$. Cz. Madajczyk bardzo trafnie scharakteryzował tego „mordercę zza biurka” w jego zbrodniczych posunięciach na ziemiach polskich:

Gorliwie ofiarowywał Greiserowi jeden ze swych oddziałów policyjnych do eksterminacji gruźlików, był teoretykiem kolonizacji wschodu i żarliwym organizatorem wysiedleń Polaków, inicjatorem stosowania odpowiedzialności rodzinnej. [...] Nawet zwierzchników Koppego uderzała jego nadgorliwość, bezwzględność, pozbawiona cienia uczuć ludzkich ${ }^{109}$.

Theodor Berkelmann był następcą W. Koppego jako HSSPF w Kraju Warty, lecz krótko pełnił tam służbę, albowiem zmarł na udar mózgu 27 grudnia 1943 roku

106 W. Bartoszewski, op. cit., s. 79. SS-Hauptsturmführer Macholl napisał w więzieniu białostockim (1949) o nim: „Von dem Bach, który dopiero teraz, po kapitulacji i po zawieszeniu broni, ponownie przybrał nazwisko Zelewski, by wykazać swoje polskie pochodzenie [...]”, zob. S. Datner, op. cit., s. 42.

107 C. Madajczyk, Polityka III Rzeszy w okupowanej Polsce, t. I, Warszawa 1970, s. 107; idem, Faszyzm i okupacje 1938-1945. Wykonywanie okupacji przez państwa Osi w Europie, t. I, Poznań 1984, s. 153. Wedle niemieckiego badacza Johannesa Kolla Seyß-Inquart w dzieciństwie i młodości nie był nastawiony wrogo ani wobec Żydów, ani wobec Czechów czy Słowaków (urodził się na Morawach). W domu rodzinnym radykalna ideologia nie była w modzie, wręcz przeciwnie, ojciec Arthura miał poglądy liberalne i odnosił się przyjaźnie do Żydów. Okres „radykalizacji” Seyß-Inquarta to lata po 1918 roku. Służba w GG była sui generis punktem granicznym w biografii tego dostojnika nazistowskiego: Seyß-Inquart wiedział o całej niemieckiej zbrodniczej polityce w GG i w pełni ją aprobował (np. akcja AB). Zdaniem Kolla Seyß-Inquart był jednym z nielicznych nazistów austriackich, których Hitler naprawdę cenił i szanował, zob. J. Koll, op. cit., s. 127, $134-135,140$.

108 C. Madajczyk, Faszyzm i okupacje 1938-1945..., s. 182-183. Autor w innym miejscu pisał, że „po przyjściu Wilhelma Koppego do GG regułą stało się tracenie za zabicie jednego urzędnika niemieckiego 50 Polaków, a za akcję dywersyjną na pociąg - 100-150 Polaków. Ponadto policja aresztowała jako zakładników rodziców i krewnych osób poszukiwanych" (ibidem, s. 224).

109 C. Madajczyk, Polityka III Rzeszy w okupowanej Polsce, t. II, Warszawa 1970, s. 358 oraz ważna pozycja: S. Datner, Wilhelm Koppe. Nieukarany zbrodniarz hitlerowski, Warszawa-Poznań 1963, passim. 
w Poznaniu, gdzie został pochowany ${ }^{110}$. Ernst Zörner po zakończeniu I wojny był członkiem Grenzschutz Ost w Gdańsku (do października 1919), co miało niewątpliwie antypolską wymowę. Znał osobiście Hitlera, któremu miał oddać jakieś „usługi” w latach 30., był powiązany z Goebbelsem i uważany za „człowieka” Hansa Franka. Ten były nadburmistrz Drezna w listopadzie 1939 roku został komisarycznym komisarzem miasta Krakowa, gdzie ze względów taktycznych odznaczał się relatywnie elastycznym stosunkiem do Polaków. 22 lutego 1940 roku został wprowadzony na urząd gubernatora Dystryktu Lublin i na tym stanowisku zdaniem Z. Mańkowskiego

starał się realizować przede wszystkim te założenia polityki Hansa Franka, które zmierzały do maksymalnej, ale utrzymanej w granicach racjonalności eksploatacji ekonomicznej powierzonego mu obszaru oraz do pełnej koncentracji władzy w swoich rękach, a więc podporządkowania wszystkich działających tu agend, łącznie z pionem SS i policji111.

Jakob Sporrenberg sprawował funkcję Dowódcy SS i Policji w Lublinie, gdzie zapisał się niechlubną kartą, a za swoje zbrodnie w Polsce został po wojnie stracony ${ }^{112}$. Richard Türk - był funkcjonariuszem nazistowskim w GG (Dystrykt Lublin), należał do „zbrodniczej” ekipy SS-Gruppenführera Odilo Globocnika jako organizator zagłady Żydów (m.in. był kierownikiem referatu spraw ludnościowych de facto spraw żydowskich w urzędzie gubernatora lubelskiego) ${ }^{113}$. SS-Gruppenführer Karl Zech był pierwszym Dowódcą SS i Policji w Krakowie — pełnił tę funkcję od września 1939114. SA-Brigadeführer Wilhelm Heerde był z wykształcenia rzeźbiarzem, od marca 1941 roku dyrektorem Staatliche Kunstgewerbeschule Krakau w Krakowie aż do likwidacji tej instytucji w marcu 1943 roku ${ }^{115}$. Christian Opdenhoff był pełnomocnikiem Rudolfa Hessa (Hess był Stellvertreter des Führers) przy generalnym gubernatorze, był również członkiem SS (SS-Oberführer) ${ }^{116}$. SS-Oberführer Günther Claassen przez krótki czas był

110 Główny dziennik nazistowski w Kraju Warty „Ostdeutscher Beobachter” napisał o zmarłym Berkelmannie między innymi: „Der Verstorbene ist am 9. November 1943 als Nachfolger des nach Krakau versetzten Höheren SS- und Polizeiführers, SS-Obergruppenführers Koppe, nach Posen gekommen. Trotz der kurzen Zeit seiner Amtstätigkeit in unserem Gau hat er sich bei allen Personen, Dienststellen und Behörden mit denen er in Berührung kam, große Wertschätzung erworben. Sein Hinscheiden bedeutet für das Wartheland einen großen Verlust.”, zob. SS-Obergruppenführer Theodor Berkelmann, „Ostdeutscher Beobachter” 1943, nr 359, 29 grudnia 1943 — taka „laurka” oznaczała po prostu, że Berkelmann był fanatycznym nazistowskim siepaczem.

111 Z. Mańkowski, Między Wista a Bugiem 1939-1944, Lublin 1982, s. 106-107; C. Madajczyk, Polityka III Rzeszy..., t. I, s. 110.

112 W roku 1941 miał popaść w jakąś depresję i zdaniem RFSS był „zbyt miękki”. Funkcję SSPF w Lublinie pełnił od lipca 1943 do kwietnia 1944, zob. C. Madajczyk, Polityka III Rzeszy..., t. II, s. 354.

113 Z. Mańkowski, Między Wistą a Bugiem 1939-1944..., s. 92, 116, 191-193.

114 T. Wroński, Kronika okupowanego Krakowa, Kraków 1974, s. 22.

115 Gr1943, biogram Heerde Wilhelm, s. 234.

116 C. Madajczyk, Polityka III Rzeszy..., t. I, s. 107. 
jesienią 1939 prezydentem policji w Warszawie i ponosi odpowiedzialność za pierwsze niemieckie zbrodnie.

Prawdopodobnie Lothar Rethel, gdański nazistowski funkcjonariusz partyjny do spraw rolnictwa i chłopstwa nosił polsko brzmiące nazwisko Retelsky, które zmienił na niemieckie Rethel (? ${ }^{117}$. SS-Oberführer Dr Günther Palten (wcześniej Patschowsky) jesienią 1939 został mianowany przez Gauleitera Forstera prezydentem rejencji bydgoskiej w Reichsgau Danzig-Westpreussen ${ }^{118}$. Ralf Brockhausen: działacz gdańskiej NSDAP przed 1933, później Reichsamtsleiter w Reichsleitung NSDAP, SS-Standartenführer, był od 1940 pełnomocnikiem Greisera (jako Beauftragter des Reichsgaues Wartheland) w Berlinie ${ }^{119}$.

Erich Koch jako Gauleiter i nadprezydent Prus Wschodnich, szef administracji cywilnej okręgu białostockiego oraz Komisarz Rzeszy na Ukrainie dopuścił się wielu zbrodni na ludności polskiej, żydowskiej, ukraińskiej, białoruskiej, rosyjskiej itd. (mordowanie, zsyłanie do obozów koncentracyjnych i zagłady, wysiedlenia, konfiskaty majątków i mienia, germanizacja) ${ }^{120}$. Waldemar Magunia, jako człowiek E. Kocha, został jego zastępcą jako stellv. Chef der Zivilverwaltung okręgu białostockiego, de facto rządził tam, zastępując Kocha, który niezbyt interesował się tym terenem, później zaś został generalnym komisarzem w Kijowie ${ }^{121}$. Kolejny człowiek E. Kocha, Paul Dargel, wysokiej rangi działacz wschodniopruskiej NSDAP (Gauorganisationsleiter, Gauschulungsleiter), od 1940 był prezydent rejencji w Ciechanowie. Dargel wraz z Gauleiterem Kochem byli odpowiedzialni za wysiedlenia ludności polskiej, zwłaszcza chłopstwa, z terenów rejencji ciechanowskiej i jej germanizację (planowano uczynić te tereny

117 Autor biografii Alberta Forstera Dieter Schenk wspomniał o naradzie zorganizowanej w listopadzie 1939 roku w Gdańsku pod kierownictwem tamtejszego HSSPF Hildebrandta dotyczącej wysiedleń ludności polskiej i żydowskiej z Reichsgau Danzig-Westpreußen, na której był obecny „okręgowy przywódca chłopów Retelsky” - ówczesnym Landesbauernführerem był właśnie Lothar Rethel, SS-Oberführer, zob. D. Schenk, op. cit., s. 256.

118 C. Madajczyk, Polityka III Rzeszy..., t. I, s. 78.

119 Gr1943, s. 172.

120 C. Madajczyk, Polityka III Rzeszy..., t. I, t. II, passim oraz R. Meindl, op. cit., passim. Szymon Datner, znawca dziejów niemieckiej okupacji Białostocczyzny pisał o Erichu Kochu: „E. Koch był nie tylko najwyższym czynnikiem partyjnym, politycznym i administracyjnym w Okręgu Białostockim — podobnie jak nim był w Prusach Wschodnich oraz w okupowanej Ukrainie - lecz także najwyższym czynnikiem kształtującym politykę policyjną, a więc [...] politykę dyskryminacji i eksterminacji w stosunku do miejscowej ludności. [...] Reasumując, należy stwierdzić [...], że pod względem zakresu władzy Kocha można porównać jedynie z Hansem Frankiem, przy czym rozmiarami popełnionych zbrodni Koch góruje nad Frankiem”, zob. S. Datner, Niemiecki okupacyjny aparat bezpieczeństwa..., s. 12-13. Wspomniany Macholl napisał o nim: „O Erichu Kochu można bez ogródek powiedzieć, że nienawidził Polaków" (Ibidem, s. 31).

121 C. Madajczyk., Faszyzm i okupacje 1938-1945..., s. 148, 625. Magunia (1902-1974), członek NSDAP od 1925 roku (jeden z największych weteranów partii nazistowskiej w Prusach Wschodnich) był z zawodu piekarzem, a po 1933 szefem DAF w Gau Ostpreußen. Wedle biografa E. Kocha Ralfa Meindla, Magunia „finanzierte die ostpreußische NSDAP Mitte der zwanziger Jahre praktisch allein”, zob. R. Meindl, Ostpreußens Gauleiter..., s. 85. 
miejscem osadnictwa synów chłopów pruskich $)^{122}$. Hans Adolf Prützmann był jednym z największych zbrodniarzy wśród elity SS (prawdopodobnie pod koniec wojny został awansowany do stopnia SS-Oberstgruppenführera), pełniąc funkcję Wyższego Dowódcy SS i Policji w Królewcu, w krajach bałtyckich i północnej Rosji czy jako Najwyższy Dowódca SS i Policji na Ukrainie stykał się z problematyką polską - kierował licznymi akcjami pacyfikacyjnymi na przykład w okręgu białostockim czy rejencji ciechanowskiej (okolice Ciechanowa czy Łomży) $^{123}$. Walczący we Freikorpsie na Górnym Śląsku po zakończeniu I wojny działacz wschodniopruskiej NSDAP Hermann Bethke (1900-1940) w 1939 roku został pierwszym prezydentem rejencji w Ciechanowie ${ }^{124}$.

Georg Joschke był jednym z najważniejszych nazistowsko zorientowanych przywódców mniejszości niemieckiej w Polsce międzywojennej (działacz JdP), a po wybuchu wojny został Kreisleiterem Zabrza (1939-1941/1945) i jednocześnie Katowic (1939-1941), a ,jego nominacja była wyjątkowa, ponieważ należał do grupy górnośląskich volksdeutschy. Przed wojną był działaczem JdP, a w 1939 r. organizował oddziały złożone z niemieckich uciekinierów z polskiego Górnego Śląska" 125 . Richard Preiß był Kreisleiterem polskiej części Lublińca w latach 1939$-1940^{126}$. Max Fillusch w latach 1933-1945 roku był nadburmistrzem Zabrza ${ }^{127}$, zatem musiał „ocierać się” o kwestie polskie na Górnym Śląsku — przykładowo Fillusch w 1930 jako poseł do Reichstagu publicznie szerzył hasło zbrojnego odebrania Polsce województwa śląskiego ${ }^{128}$. Alfred Hawellek w latach 1940-1942 był Kreisleiterem NSDAP w Rybniku (Rybnik należał w latach 1922-1939 do Polski),

122 C. Madajczyk, Polityka III Rzeszy..., t. I, s. 447-448. Po okresie pełnienia funkcji prezydenta rejencji w Ciechanowie Dargel objął wysokie stanowisko w Komisariacie Rzeszy Ukraina, a następnie trafił do Kancelarii NSDAP jako ekspert do spraw wschodnich, zob. C. Madajczyk, Faszyzm i okupacje 1938-1945..., s. 448.

123 K. Grünberg, op. cit., s. 207. Być może także SS-Oberstgruppenführer Prützmann miał słowiańskie (polskie?) pochodzenie. Likwidator getta warszawskiego, Jürgen Stroop, był nieomal wielbicielem Prützmanna. Kazimierz Moczarski zapamiętał jedną z wypowiedzi Stroopa o Prützmannie: „Hans Adolf Prützmann - ciągnął Stroop — urodził się (jak mi kiedyś opowiadał) w 1901 roku nad Zalewem Wiślanym, w Tolkmicku...

— To z pewnością płynęła w nim krew słowiańska, jak w von dem Bachu-Zelewskim, którego matka mówiła bardzo dobrze po polsku i językiem tym posługiwała się od dzieciństwa na Mazurach, skąd pochodziła ich rodzina — włączył się do rozmowy Gustav Schielke.

- Ma pan trochę racji — odpowiedział Stroop. — Babka generała Prützmanna także była Polką.", zob. K. Moczarski, Rozmowy z katem, s. 346.

124 R. Meindl, op. cit., s. 108. Bethke był zaufanym człowiekiem Gauleitera Kocha.

125 R. Kaczmarek, Pod rzadami gauleiterów..., s. 113.

126 R. Kaczmarek, Górny Ślask podczas II wojny światowej. Między utopia niemieckiej władzy narodowej a rzeczywistościa okupacji na terenach wcielonych do Trzeciej Rzeszy, Katowice 2006, s. 274.

127 R. Kaczmarek, Pod rzadami gauleiterów..., s. 68-69.

128 F. Połomski, Uwagi o działalności NSDAP na Ślasku Opolskim, „Studia Śląskie” X 1966, s. 133. 
a wcześniej był działaczem NSDAP w Raciborzu ${ }^{129}$. Paul Roden (do 1936 noszący nazwisko Rorzyczka) był działaczem najpierw na Dolnym, później na Górnym Śląsku — w latach 1941-1942 był kierownikiem sztabu okręgu (Gaustabsamtsleiter Gau Oberschlesien), jednak jako człowiek byłego Gauleitera Wagnera nie cieszył się sympatią jego następcy Fritza Brachta. Roden jesienią 1939 był odpowiedzialny za kontakty z górnośląskimi volksdeutschami i mozolne budowanie komórek terenowych NSDAP ${ }^{130}$. Udo von Woyrsch, doświadczony oficer SS ze Śląska (jeden z założycieli śląskiej SS), był dowódcą specjalnej Einsatzgruppe zur besonderen Verwendung, która działała na terenie Górnego Śląska i była odpowiedzialna za „stłumienie” działań „powstańców” na Górnym Śląsku tj. osób walczących $\mathrm{z}$ nadciągającymi Niemcami - w praktyce oznaczało to aresztowania, morderstwa (np. Żydów w Zagłębiu Dąbrowskim), egzekucje czy spalenie synagogi w Katowicach ${ }^{131}$. SS-Obergruppenführer Hanns Albin Rauter, Niemiec austriacki, który przez nominację na Wyższego Dowódcę SS i Policji w Holandii wdarł się do absolutnej czołówki dowódców SS, wcześniej działał na Śląsku, gdzie pełnił funkcję szefa sztabu (Stabsführer) SS-Oberabschnitt Südost we Wrocławiu ${ }^{132}$. Albrecht Schmelt w 1939 roku został mianowany przez J. Wagnera prezydentem rejencji opolskiej, następnie jako osoba blisko związana z SS i Himmlerem pełnił funkcję pełnomocnika RFSS do spraw zatrudnienia obcej siły roboczej na Górnym Śląsku (Sonderbeuaftragter des RFSS für fremdvölkischen Arbeitseinsatz in Oberschlesien). Od 1941 był kierownikiem urzędu do spraw urzędniczych w Gau Oberschlesien i Gau Niederschlesien; był szefem tzw. Organisation Schmelt, która tworzyła obozy pracy (niewolniczej) dla Żydów i Polaków na Dolnym i Górnym Śląsku, tudzież w Zagłębiu Dąbrowskim ${ }^{133}$. Josef Schönwälder był niemal przez cały okres okupacji nadburmistrzem Sosnowca oraz starostą - ten działacz partyjny nie był zbyt wysoko oceniany przez przełożonych (negatywnie oceniano jego zdolności organizacyjne), co być może miało wpływ na jego „osadzenie” w Sosnowcu właśnie ${ }^{134}$.

129 R. Kaczmarek, Górny Śląsk podczas II wojny..., s. 274.; idem, Pod rzadami gauleiterów..., s. 115.

130 R. Kaczmarek, Pod rzadami gauleiterów..., s. 88, 109.

131 R. Kaczmarek, Górny Śląsk podczas II wojny..., s. 76-77. C. Madajczyk pisał o jednostce specjalnej von Woyrscha: „Grupa policyjna dowodzona przez SS-Gruppenführera [błąd — von Woyrsch od 1935 roku posiadał stopien SS-Obergruppenführera - W.K.] von Woyrscha rozstrzeliwała bez sądów i z taką brutalnością, że doszło do ostrych konfliktów z oddziałami wojskowymi. W konsekwencji nastąpiła zmiana dowódcy, został nim SS-Oberführer dr Rasch”, zob. C. Madajczyk, Polityka III Rzeszy..., t. I, s. 48.

132 P. Longerich, Heinrich Himmler. Biographie, München 2010, s. 510.

133 R. Kaczmarek, Pod rzadami gauleiterów..., s. 110, 191-193; idem, Górny Ślask podczas II wojny..., s. 229-232; Autobiografia Rudolfa Hössa komendanta obozu oświęcimskiego..., s. 205-207.

134 Ryszard Kaczmarek napisał, że „Sosnowiec oraz pozostałe miejscowości we wschodniej części rejencji katowickiej traktowane były bowiem przez niemieckich urzędników jako tereny niezapewniające możliwości uwieńczenia sukcesem własnej kariery", natomiast Schönwäldera cechowała „,agresywność i brak skłonności do słuchania poleceń służbowych (zarzucano mu, że zajmuje 
Werner Lorenz początkowo był członkiem SS w Wolnym Mieście Gdańsku (i właścicielem majątku Mariensee) i tam aktywnie działał. Jako szef SS-Volksdeutsche Mittelstelle zajmował się sprawami Niemców etnicznych żyjących poza granicami Rzeszy — w tym charakterze zajmował się sprawami Polski i żyjącą tam mniejszością niemiecką (kontakty z Wiesnerem, Kuhnertem, Wolffem etc.). W czasie II wojny SS-VOMI zajmowała się sprawami osadnictwa Niemców etnicznych, chociażby na ziemiach wcielonych bezpośrednio do Rzeszy ${ }^{135}$.

$$
* * *
$$

Większość naszkicowanych domniemanych i rzeczywistych „spotkań” przyszłych prominentów nazistowskich z Polską, Polakami, polskością miała charakter „negatywny" lub wrogi, co było związane z XIX-wiecznymi procesami i zjawiskami jak powstawanie nowoczesnych narodów, państw narodowych (Rzesza Niemiecka 1871), nacjonalizmów. Ważnym miejscem w tych negatywnych „spotkaniach" były ziemie, które Niemcy utraciły na rzecz Polski po 1918 roku (Wielkopolska, Śląsk, Pomorze). To uderzające, jak wielu przyszłych prominentów nazistowskich przyjmowało zdecydowanie antypolską postawę przed swym wstąpieniem do NSDAP (np. w okresie walk niemiecko-polskich w latach 1918-1921).

Przy nominacjach na stanowiska $\mathrm{w}$ niemieckim aparacie okupacyjnym na ziemiach polskich (GG, ziemie wcielone do Rzeszy) nie kierowano się chyba jakimś „kluczem” związanym z kontaktami danych osób z polskością, ich znajomości Polski i Polaków (bo czy istnieli w ogóle tacy narodowi socjaliści?!). Zatem kontakty określonych prominentów nazistowskich z polskością nie stanowiły żadnego „handicapu” przy obsadzie stanowisk na okupowanych przez Niemców ziemiach polskich. Wbrew pozorom ani Hans Frank (który odwiedził przed wojną Polskę i prawił fałszywie komplementy gospodarzom), ani Arthur Greiser czy Albert Forster nie znali się na Polsce i jej mieszkańcach, a odznaczała ich właśnie „wściekła" nienawiść do podbitego i okupowanego kraju.

\section{Bibliografia}

Auerbach H., Die Einheit Dirlewanger, „Vierteljahreshefte für Zeitgeschichte” 1962, z. 3. Autobiografia Rudolfa Hössa komendanta obozu oświęcimskiego, Warszawa 1989.

Bajohr F., Gauleiter in Hamburg. Zur Person und Tätigkeit Karl Kaufmanns, „Vierteljahreshefte für Zeitgeschichte" 1995, z. 2.

się własnymi interesami, a nie sprawami komunalnymi). [...] Schönwälder był jednym z nielicznych landratów i nadburmistrzów w rejencji katowickiej, którzy nie mieścili się w przyjętym tutaj modelu, zgodnym z pruską pragmatyką administracyjną zatrudniania na tego rodzaju stanowiskach tylko fachowych urzędników”, zob. R. Kaczmarek, Górny Ślask i Zagtębie Dąbrowskie w planach niemieckich podczas II wojny światowej, [w:] Ślasko-zagłębiowskie konfrontacje historyczne (XIX-XX wiek), red. M.W. Wanatowicz, Katowice 1999, s. 141-142.

135 P. Longerich, op. cit., s. 403, 458; M. Cygański, SS w polityce zagranicznej..., s. 21, passim. 
Bartoszewski W., Prawda o von dem Bachu, Warszawa-Poznań 1961.

Boberski E., Grosse Deutsche aus Oberschlesien, „Oberschlesischer Heimatkalender für das Jahr” 1943.

Borejsza J.W., Antyslawizm Adolfa Hitlera, Warszawa 1988.

Borejsza J.W., Śmieszne sto milionów Stowian: wokół światopogladu Adolfa Hitlera, Warszawa 2006.

Cimała B., Heines Edmund, [w:] Encyklopedia Powstań Śląskich, Opole 1982.

Cygański M., SS w polityce zagranicznej III Rzeszy w latach 1934-1945, Warszawa-Wrocław 1975.

Cygański M., SS w pruskich prowincjach Ślaska w latach 1929-1935, „Studia Śląskie” XXV, 1974, Seria Nowa.

Cygański M., Z dziejów okupacji hitlerowskiej w Łodzi, Łódź 1965.

Czubiński A., Powstanie Wielkopolskie 1918-1919. Geneza - charakter - znaczenie, Poznań 2002.

Datner S., Niemiecki okupacyjny aparat bezpieczeństwa w okręgu białostockim (1941-1944) w świetle materiałów niemieckich (opracowania Waldemara Macholla), „Biuletyn Głównej Komisji Badania Zbrodni Hitlerowskich w Polsce" XV, 1965.

Datner S., Wilhelm Koppe. Nieukarany zbrodniarz hitlerowski, Warszawa-Poznań 1963.

Der Deutsche Reichstag 1936 III. Wahlperiode nach dem 30. Januar 1933, Berlin 1936.

Der Großdeutsche Reichstag 1938 IV. Wahlperiode (nach dem 30. Januar 1933), Berlin 1938.

Der Grossdeutsche Reichstag. IV. Wahlperiode, beginn am 10. April 1938 verlängert bis zum 30. Januar 1947, Berlin 1943.

Epstein C., Wzorcowy nazista. Arthur Greiser i okupacja Kraju Warty, Wrocław 2011.

Grünberg K., SS-czarna gwardia Hitlera, Warszawa 1985.

Heiber H., Aus den Akten des Gauleiters Kube, „Vierteljahreshefte für Zeitgeschichte” 1956, z. 1.

Iranek-Osmecki K., Powołanie i przeznaczenie. Wspomnienia oficera Komendy Głównej AK, Warszawa 2004.

Jérome G., Les milices d'autoprotection de la communauté allemande de Pomérélie, Posnanie et Silésie Polonaise, „Guerres mondiales et conflits contemporains” 1991, nr 163.

Kaczmarek R., Górnośląscy Niemcy w administracji niemieckiej rejencji katowickiej, [w:] Górny Śląsk i Górnoślązacy w II wojnie światowej, red. W. Wrzesiński, Bytom 1997.

Kaczmarek R., Górny Śląsk i Zagłębie Dąbrowskie w planach niemieckich podczas II wojny światowej, [w:] Ślasko-zagłębiowskie konfrontacje historyczne (XIX-XX wiek), red. M.W. Wanatowicz, Katowice 1999.

Kaczmarek R., Górny Śląsk podczas II wojny światowej. Między utopia niemieckiej wspólnoty narodowej a rzeczywistościa okupacji na terenach wcielonych do Trzeciej Rzeszy, Katowice 2006.

Kaczmarek R., Pod rząami gauleiterów. Elity i instancje władzy w rejencji katowickiej $w$ latach 1939-1945, Katowice 1998.

Koll J., From the Habsburg Empire to the Third Reich: Arthur Seyß-Inquart and National Socialism, [w:] Austrian Lives, red. G. Bischof, F. Plasser, E. Maltschnig, New Orleans 2012.

Król E.C., Polska i Polacy w propagandzie narodowego socjalizmu w Niemczech 1919-1945, Warszawa 2006.

Lesiuk W., Heydebreck Hans Adam Peter von, [w:] Encyklopedia Powstań Ślaskich, Opole 1982.

Lesiuk W., Hoefer Karl Julius Robert, [w:] Encyklopedia Powstań Śląskich, Opole 1982.

Longerich P., Heinrich Himmler. Biographie, München 2010.

Łuczak C., Arthur Greiser hitlerowski władca w Wolnym Mieście Gdańsku i w Kraju Warty, Poznań 1997.

Madajczyk C., Faszyzm i okupacje 1938-1945. Wykonywanie okupacji przez państwa Osi w Europie, t. I, Poznań 1984.

Madajczyk C., Polityka III Rzeszy w okupowanej Polsce, t. I, Warszawa 1970.

Studia nad Autorytaryzmem i Totalitaryzmem 38, nr 2, 2016

(C) for this edition by CNS 
Madajczyk C., Polityka III Rzeszy w okupowanej Polsce, t. II, Warszawa 1970.

Mańkowski Z., Między Wista a Bugiem 1939-1944, Lublin 1982.

Matelski D., Niemcy w Polsce w XX wieku, Warszawa-Poznań 1999.

Meindl R., Ostpreußens Gauleiter. Erich Koch - eine politische Biographie, Osnabrück 2007.

Mendel E., Lesiuk W., Freikorps von Aulock, [w:] Encyklopedia Powstań Śląskich, Opole 1982.

Moczarski K., Rozmowy z katem, Warszawa 2000.

Orłowski H., Polnische Wirthschaft. Nowoczesny niemiecki dyskurs o Polsce, Olsztyn 1998.

Połomski F., Uwagi o działalności NSDAP na Ślasku Opolskim, „Studia Śląskie” X, 1966.

Rebentisch D., Lammers Hans Heinrich, [w:] Neue Deutsche Biographie, t. 13, Berlin 1982.

Reichstag-Handbuch VI. Wahlperiode 1932, Berlin 1932.

Reichstag-Handbuch IX. Wahlperiode 1933, Berlin 1934.

Ryszka F., Polityka hitlerowska na Śląsku (1933-1945). Uwagi ogólne i postulaty badawcze, „Studia Śląskie" X 1966.

Schenk D., Albert Forster gdański namiestnik Hitlera. Zbrodnie hitlerowskie w Gdańsku i Prusach Zachodnich, Gdańsk 2002.

Schulz A., Wegmann G., Zienke D., Die Generale der Waffen-SS und der Polizei. Die militärische Werdegänge der Generale, sowie der Ärzte, Veterinäre, Intendanten, Richter und Ministerialbeamten im Generalsrang, t. 2, Bissendorf 2005.

Speer A., Dzienniki ze Spandau, Warszawa 2010.

Szarota T., Niemcy i Polacy. Wzajemne postrzeganie i stereotypy, Warszawa 1996.

Thomas W.I., Thomas D.S., The Child in America. Behavior problems and programs, New York 1928.

Wildt M., Generation des Unbedingten. Das Führungskorps des Reichssicherheitshauptamtes, Hamburg 2003.

Wroński T., Kronika okupowanego Krakowa, Kraków 1974.

\section{ALLEGED AND ACTUAL CONTACTS OF PROMINENT NAZIS WITH POLISHNESS BEFORE 1933}

\section{Summary}

The article is an attempt to examine the contacts of prominent Nazis with Polishness before 1933. The author looks at these contacts with regard to the place of birth, living in a given place until 1918, living in a given place in the inter-war period (1918-1933), participation in the First World War in Poland, participation in Polish-German fighting in 1918-1921, having a Polish-sounding name and impact of all these factors on the period of the Second World War (German occupation of Poland).

Keywords: national socialism, Third Reich, Polish-German fighting, German minority in Poland, German occupation in Poland.

Wojciech Kapica

adres e-mail: capit432@onet.pl

Studia nad Autorytaryzmem i Totalitaryzmem 38, nr 2, 2016

(C) for this edition by CNS 